\title{
X-Ray Diffraction and Infrared Spectroscopy Data Review Analyses of the Calcium Phosphates
}

\author{
Smail El Makhloufy 1,*(D), Rachida Oubouaza ${ }^{1(\mathbb{D})}$, Ali Ouasri ${ }^{2}{ }^{(\mathbb{D}}$, Said Belaaouad ${ }^{1(\mathbb{C}}$ \\ 1 Laboratory of Physical Chemistry of Materials, FSBM, Hassan II University of Casablanca, Morocco; \\ smail.elmakhloufy@gmail.com (S.E); oubouazarachida01@gmail.com (R.O); sbelaaouad@yahoo.fr (S.B.); \\ 2 Laboratory (ReSIP), Regional Center of Education and Formation Trades, Madinat Al Irfane, Souissi, BP 6210 Rabat, \\ Morocco; aouasri@yahoo.fr (A.O.); \\ * Correspondence: smail.elmakhloufy@gmail.com (S.E);
}

Scopus Author ID 57212566052

Received: 15.02.2021; Revised: 25.03.2021; Accepted: 2.04.2021; Published: 26.04.2021

Abstract: The objective of this literature reviews is to report the various methods used in the synthesis of the calcium monophosphates and condensed phosphates compounds, such as the co-precipitation method, Boulle's process, solid-state reactions, hydrothermal synthesis, and thermal dehydration, and present the crystalline data of these salts as classified from the hexagonal to the triclinic system. For the monophosphates, the compounds with $\left(\mathrm{PO}_{4}\right)^{3-}$ groups crystallized in the hexagonal, rhombohedral, trigonal, orthorhombic, and monoclinic systems, against the compounds with $\left(\mathrm{HPO}_{4}\right)^{2-}$ and $\left(\mathrm{H}_{2} \mathrm{PO}_{4}\right)-$, which are crystallized in low symmetry systems (monoclinic, and triclinic). For the long polyphosphates chain $\left(\mathrm{PO}_{3}{ }^{-}\right)_{\mathrm{n}}$, where the formula contains one $\left(\mathrm{PO}_{4}\right)^{3-}$ group, the compounds crystallized in the high possible symmetry (tetragonal systems); the compounds of a formula containing two, three, and four $\left(\mathrm{PO}_{4}\right)^{3-}$ groups are crystallized in the lower symmetry systems (monoclinic, and triclinic). In the anhydrous cyclotetraphosphates, the substitution of $2 \mathrm{~K}^{+}$by $\mathrm{Ca}^{2+}$ induced lowering symmetry from the tetragonal system in $\mathrm{CaK}_{2} \mathrm{P}_{4} \mathrm{O}_{12}$ to the triclinic system in $\mathrm{Ca}_{2} \mathrm{P}_{4} \mathrm{O}_{12}$. The calcium cyclohexaphosphates are all found to be hydrate compounds. With ammonium cations, the $\left(\mathrm{NH}_{4}\right)_{6} \mathrm{P}_{6} \mathrm{O}_{18} \cdot 1 \mathrm{H}_{2} \mathrm{O}$ crystallized in the orthorhombic system, as a highly symmetrical system found in this phosphate type. Besides, the study is extended to review the inferred characterization made particularly for anions, $\quad \mathrm{PO}^{3-} \quad$ in $\gamma-\mathrm{Ca}\left(\mathrm{PO}_{3}\right)_{2}, \quad \mathrm{PO}_{4}{ }^{3-}$ in $\mathrm{CaHPO}_{4}, \quad \mathrm{P}_{2} \mathrm{O}_{7}{ }^{4-}$ in $\beta-\mathrm{Ca}_{2} \mathrm{P}_{2} \mathrm{O}_{7}, \quad \mathrm{P}_{3} \mathrm{O}_{9}{ }^{3-}$ in $\quad \mathrm{MnCa}_{2}\left(\mathrm{P}_{3} \mathrm{O}_{9}\right)_{2}, \quad \mathrm{P}_{4} \mathrm{O}_{12}{ }^{4-}$ in $\mathrm{Ca}_{2} \mathrm{P}_{4} \mathrm{O}_{12} \cdot 1.5 \mathrm{H}_{2} \mathrm{O}_{2} \cdot 3 \mathrm{H}_{2} \mathrm{O}$ and $\mathrm{P}_{6} \mathrm{O}_{18}{ }^{6-}$ in $\mathrm{Ca}_{2} \mathrm{~K}_{2} \mathrm{P}_{6} \mathrm{O}_{18} \cdot 6 \mathrm{H}_{2} \mathrm{O}$.

Keywords: chemical synthesis; X-ray diffraction; infrared vibration; condensed phosphate; monophosphate; calcium.

(C) 2021 by the authors. This article is an open-access article distributed under the terms and conditions of the Creative Commons Attribution (CC BY) license (https://creativecommons.org/licenses/by/4.0/).

\section{Introduction}

Materials based on monophosphates and condensed phosphates associated with calcium (Ca-P) have been developed considerably during recent decades. These compounds are found to be interesting in many fields of applications such as bioactive ceramics, biology, building materials (cement), and biotechnological materials [1-4]. For this reason, several review articles were interested in calcium phosphate [5,6].On the other hand, the chemical synthesis, crystalline data, and infrared spectroscopy of some characteristic anions of monophosphates and condensed phosphates associated with some alkaline earth elements $\left[\mathrm{M}^{\mathrm{II}}=\mathrm{Ba}, \mathrm{Sr}\right][7,8]$ and transition elements[M=Mn][9] have been recently reviewed. 
In the present work, we will develop a review study to report and analyses the synthesis, Xray, and infrared characteristics of monophosphates and condensed phosphates associated with calcium (Ca-P).

\section{Monophosphates $\mathrm{PO}_{4}{ }^{3-}$}

\subsection{Synthesis.}

In this part, we present the synthesis details of monophosphate associated with calcium, which has been prepared by various synthetic methods, such as: the co-precipitation method, hydrothermal synthesis, and thermal method.

\subsection{1. $\mathrm{Ca}\left(\mathrm{H}_{2} \mathrm{PO}_{4}\right)_{2} \cdot \mathrm{H}_{2} \mathrm{O}$.}

This compound was prepared by Bac et al. [10] by solution precipitation methods using calcium carbonate $\mathrm{CaCO}_{3}$ and phosphoric acid $\mathrm{H}_{3} \mathrm{PO}_{4}$ as starting materials. In a typical procedure, $23 \mathrm{~g}$ of $\mathrm{H}_{3} \mathrm{PO}_{4}$ was diluted with $14 \mathrm{~g}$ of water, and then the formed solution was heated to $90^{\circ} \mathrm{C}$ in a water bath. Calcium carbonate $\mathrm{CaCO}_{3}$ was then gradually added in small portions, according to the following chemical reaction:

$$
\mathrm{CaCO}_{3}+2 \mathrm{H}_{3} \mathrm{PO}_{4} \longrightarrow \mathrm{Ca}\left(\mathrm{H}_{2} \mathrm{PO}_{4}\right)_{2} \cdot \mathrm{H}_{2} \mathrm{O}+\mathrm{CO}_{2}
$$

The so-obtained solution was stirred continuously for c.a. 1 hour to form a homogeneous mixture. The product was dried at $95^{\circ} \mathrm{C}$ and obtained $25 \mathrm{~g}$ white powder.

\subsection{2. $\mathrm{Ca}\left(\mathrm{H}_{2} \mathrm{PO}_{4}\right)_{2}$}

This anhydrous compound was obtained by Bac et al. [10,11] by thermal dehydration of the hydrated phase $\mathrm{Ca}\left(\mathrm{H}_{2} \mathrm{PO}_{4}\right)_{2} \cdot \mathrm{H}_{2} \mathrm{O}$ at $120{ }^{\circ} \mathrm{C}$, according to the following chemical reaction:

$$
\mathrm{Ca}\left(\mathrm{H}_{2} \mathrm{PO}_{4}\right)_{2} \cdot \mathrm{H}_{2} \mathrm{O} \longrightarrow \mathrm{Ca}\left(\mathrm{H}_{2} \mathrm{PO}_{4}\right)_{2}+\mathrm{H}_{2} \mathrm{O}
$$

\subsection{3. $\mathrm{CaHPO}_{4} \cdot 2 \mathrm{H}_{2} \mathrm{O}$.}

The titled crystal was prepared by Curry et al. [12] by neutralization of phosphoric acid $\mathrm{H}_{3} \mathrm{PO}_{4}$ with calcium hydroxide $\mathrm{Ca}(\mathrm{OH})_{2}$ at $\mathrm{pH}$ between 3 and 4, and at room temperature, according to the following chemical reaction:

$$
\mathrm{Ca}(\mathrm{OH})_{2}+\mathrm{H}_{3} \mathrm{PO}_{4} \longrightarrow \mathrm{CaHPO}_{4} \cdot 2 \mathrm{H}_{2} \mathrm{O}
$$

\subsection{4. $\mathrm{CaHPO}_{4}$.}

This anhydrous compound was obtained by Dickens et al. [13] by thermal dehydration of the hydrated phase $\mathrm{CaHPO}_{4} .2 \mathrm{H}_{2} \mathrm{O}$ at $180{ }^{\circ} \mathrm{C}$, according to the following chemical reaction:

$$
\mathrm{CaHPO}_{4} \cdot 2 \mathrm{H}_{2} \mathrm{O} \longrightarrow \mathrm{CaHPO}_{4}+2 \mathrm{H}_{2} \mathrm{O}
$$

\subsection{5. $\alpha-\mathrm{Ca}_{3}\left(\mathrm{PO}_{4}\right)_{2}$.}

Samples of $\alpha-\mathrm{Ca}_{3}\left(\mathrm{PO}_{4}\right)_{2}$ were prepared by Mathew et al. [14] by heating pressed pellets of stoichiometric amounts of $\mathrm{CaHPO}_{4}$ and calcium carbonate $\mathrm{CaCO}_{3}$, mixed with $1 \%$ cornstarch and a few drops of distilled water, to $1400^{\circ} \mathrm{C}$ for two days, like the following:

$$
2 \mathrm{CaHPO}_{4}+\mathrm{CaCO}_{3} \longrightarrow \alpha-\mathrm{Ca}_{3}\left(\mathrm{PO}_{4}\right)_{2}+\mathrm{CO}_{2}+\mathrm{H}_{2} \mathrm{O}
$$




\subsection{6. $\beta-\mathrm{Ca}_{3}\left(\mathrm{PO}_{4}\right)_{2}$.}

Yashima et al. [15] have prepared the titled compound by solid-state reactions from $\mathrm{CaHPO}_{4}$ and $\mathrm{CaCO}_{3}$. Stoichiometric amounts of $\mathrm{CaHPO}_{4}$ and calcium carbonate $\mathrm{CaCO}_{3}$ were mixed for about $1.5 \mathrm{~h}$ in an agate mortar, like the following:

$$
2 \mathrm{CaHPO}_{4}+\mathrm{CaCO}_{3} \longrightarrow \beta-\mathrm{Ca}_{3}\left(\mathrm{PO}_{4}\right)_{2}+\mathrm{CO}_{2}+\mathrm{H}_{2} \mathrm{O}
$$

The mixture was pressed into pellets under uniaxial pressure of $150 \mathrm{MPa}$. The pellets were sintered for $24 \mathrm{~h}$ at $1000{ }^{\circ} \mathrm{C}$ to obtain a single phase of $\beta-\mathrm{Ca}_{3}\left(\mathrm{PO}_{4}\right)$.

\subsection{7. $\mathrm{Ca}_{4}\left(\mathrm{PO}_{4}\right)_{2} \mathrm{O}$.}

This phase was obtained by Dickens et al.[16] by heating at high temperature a mixture of calcium carbonate $\mathrm{CaCO}_{3}$ and phosphate salts $\mathrm{Ca}_{2} \mathrm{P}_{2} \mathrm{O}_{7} . \mathrm{H}_{2} \mathrm{O}$ with a $\mathrm{Ca} / \mathrm{P}$ ratio close to 2 , according to the following chemical reaction:

$$
2 \mathrm{CaCO}_{3}+\mathrm{Ca}_{2} \mathrm{P}_{2} \mathrm{O}_{7} \cdot \mathrm{H}_{2} \mathrm{O} \longrightarrow \mathrm{Ca}_{4}\left(\mathrm{PO}_{4}\right)_{2} \mathrm{O}+\mathrm{CO}_{2}+\mathrm{H}_{2} \mathrm{O}
$$

\subsection{8. $\mathrm{Ca}_{10}\left(\mathrm{PO}_{4}\right)_{6} \mathrm{~F}_{2}$.}

This compound was prepared by Abrouki et al. [17] by the co-precipitation method using diammonium phosphate $\left(\mathrm{NH}_{4}\right)_{2} \mathrm{HPO}_{4}$, calcium nitrate $\mathrm{Ca}\left(\mathrm{NO}_{3}\right)_{2}$ and ammonium fluoride $\mathrm{NH}_{4} \mathrm{~F}$ as starting materials. In a typical procedure, $250 \mathrm{~mL}$ of a solution containing $7.92 \mathrm{~g}$ of $\left(\mathrm{NH}_{4}\right)_{2} \mathrm{HPO}_{4}$ and $1 \mathrm{~g}$ of $\mathrm{NH}_{4} \mathrm{~F}$, maintained at $\mathrm{pH}$ greater than 12 by addition of ammonium hydroxide $(15-20 \mathrm{~mL})$, were dropped under constant stirring into $150 \mathrm{~mL}$ of a solution containing $23.6 \mathrm{~g}$ calcium nitrate $\left(\mathrm{Ca}\left(\mathrm{NO}_{3}\right)_{2} \cdot 4 \mathrm{H}_{2} \mathrm{O}\right)$, according to the following chemical reaction.

$$
6\left(\mathrm{NH}_{4}\right)_{2} \mathrm{HPO}_{4}+10 \mathrm{Ca}\left(\mathrm{NO}_{3}\right)_{2}+2 \mathrm{NH}_{4} \mathrm{~F}+6 \mathrm{NH}_{4} \mathrm{OH} \rightarrow \mathrm{Ca}_{10}\left(\mathrm{PO}_{4}\right)_{6} \mathrm{~F}_{2}+20 \mathrm{NH}_{4}\left(\mathrm{NO}_{3}\right)+6 \mathrm{H}_{2} \mathrm{O}
$$

The obtained product was filtered, washed with doubly distilled water, dried overnight at $80^{\circ} \mathrm{C}$, and calcined in air at $700^{\circ} \mathrm{C}$.

\subsection{9. $\mathrm{CaZr}_{4}\left(\mathrm{PO}_{4}\right)_{6}$.}

Powder crystalline of $\mathrm{CaZr}_{4}\left(\mathrm{PO}_{4}\right)_{6}$ have been prepared by Alamo et al. [18] from mixtures of $\mathrm{ZrO}_{2}, \mathrm{NH}_{4} \mathrm{H}_{2} \mathrm{PO}_{4}$, and $\mathrm{CaCO}_{3}$ in stoichiometric proportions and heated in three steps at $800^{\circ} \mathrm{C}$ for $12 \mathrm{~h}$, at $1200^{\circ} \mathrm{C}$ for $12 \mathrm{~h}$ and at $1300^{\circ} \mathrm{C}$ for $10 \mathrm{~h}$ to obtain a single-phase, according to the following chemical reaction:

$$
4 \mathrm{ZrO}_{2}+6 \mathrm{NH}_{4} \mathrm{H}_{2} \mathrm{PO}_{4}+\mathrm{CaCO}_{3} \rightarrow \mathrm{CaZr}_{4}\left(\mathrm{PO}_{4}\right)_{6}+\mathrm{CO}_{2}+6 \mathrm{NH}_{3}+9 \mathrm{H}_{2} \mathrm{O}
$$

\subsubsection{0. $\mathrm{CsCa}_{10}\left(\mathrm{PO}_{4}\right)_{7}$ and $\mathrm{Cs}_{0.63} \mathrm{Ca}_{9.63} \mathrm{Fe}_{0.37}\left(\mathrm{PO}_{4}\right)_{7}$.}

The two compounds were prepared by Zatovsky et al. [19] by solid-state reactions from $\mathrm{CsPO}_{3}, \mathrm{CaO}$, and $\mathrm{Fe}_{2} \mathrm{O}_{3}$. The calculated amounts of $\mathrm{CsPO}_{3}, \mathrm{CaO}$, and $\mathrm{Fe}_{2} \mathrm{O}_{3}$ were ground, put into a platinum crucible, and the necessary amount of $\mathrm{H}_{3} \mathrm{PO}_{4}$ was added to the mixture, following this chemical reaction:

$$
\mathrm{CsPO}_{3}+10 \mathrm{CaO}+6 \mathrm{H}_{3} \mathrm{PO}_{4} \rightarrow \mathrm{CsCa}_{10}\left(\mathrm{PO}_{4}\right)_{7}+9 \mathrm{H}_{2} \mathrm{O}
$$




\section{$0.63 \mathrm{CsPO}_{3}+9.63 \mathrm{CaO}+0.37 \mathrm{Fe}_{2} \mathrm{O}_{3}+6.37 \mathrm{H}_{3} \mathrm{PO}_{4} \rightarrow \mathrm{Cs}{ }_{0.63} \mathrm{Ca}_{9.63} \mathrm{Fe}_{0.37}\left(\mathrm{PO}_{4}\right)_{7}+9.55 \mathrm{H}_{2} \mathrm{O}$}

The crucibles were put into the cold furnace and slowly heated up to $1073 \mathrm{~K}$. At this temperature, the flux was exposed during 40-50 min to reach homogeneity. The crystallization was performed at a rate of $30-50 \mathrm{~K} / \mathrm{h}$ down to $943-923 \mathrm{~K}$.

\subsubsection{1. $\mathrm{Ca} 9 \mathrm{Cr}\left(\mathrm{PO}_{4}\right)_{7}$.}

This compound was prepared by Zatovsky et al. [20] by solid-state reaction methods using $\mathrm{CsPO}_{3}, \mathrm{CaCO}_{3}$, and $\mathrm{Cr}_{2} \mathrm{O}_{3}$ as starting materials. In a typical procedure, a mixture ofCsPO $3, \mathrm{CaCO}_{3}$, and $\mathrm{Cr}_{2} \mathrm{O}_{3}$ was ground in an agate mortar, placed into a platinum crucible, and heated up to $1273 \mathrm{~K}$. The melt were kept at this temperature until it became homogenous (2h). The temperature was then decreased to $1053 \mathrm{~K}$ at a rate of $30 \mathrm{~K} \mathrm{~h}^{-1}$, and at this temperature, the remaining flux was decantated, according to the following chemical reactions:

$$
7 \mathrm{CsPO}_{3}+9 \mathrm{CaCO}_{3}+1 / 2 \mathrm{Cr}_{2} \mathrm{O}_{3} \rightarrow \mathrm{Ca}_{9} \mathrm{Cr}\left(\mathrm{PO}_{4}\right)_{7}+9 \mathrm{CO}_{2}+7 / 2 \mathrm{Cs}_{2} \mathrm{O}
$$

The crucible was cooled down to room temperature. The solidified melt was leached out with deionized water, and light-green crystals of $\mathrm{Ca} 9 \mathrm{Cr}\left(\mathrm{PO}_{4}\right)_{7}$ were recovered.

\subsubsection{2. $\mathrm{CaNa}_{2}\left(\mathrm{HPO}_{4}\right)_{2}$.}

This compound was prepared by Ben Chaabane et al. [21] by hydrothermal synthesis using $\mathrm{CaCl}_{2} \cdot \mathrm{xH}_{2} \mathrm{O}, \mathrm{NaCl}, \mathrm{H}_{3} \mathrm{PO}_{4}$, and $\mathrm{C}_{6} \mathrm{H}_{15} \mathrm{~N}$ as starting materials. A mixture of $\mathrm{CaCl}_{2} \cdot \mathrm{xH}_{2} \mathrm{O}$ (805 mg), $\mathrm{NaCl}(847 \mathrm{mg}), \mathrm{H}_{3} \mathrm{PO}_{4}(14.4 \mathrm{mmol})$, and $\mathrm{C}_{6} \mathrm{H}_{15} \mathrm{~N}(24.6 \mathrm{mmol})$ was placed in a Teflon vessel and filled to a degree of $80 \%$ with water (final $\mathrm{pH}=9.5$ ). The obtained product was heated at $180^{\circ} \mathrm{C}$ for 5 days, and the powder compound $\mathrm{CaNa}_{2}\left(\mathrm{HPO}_{4}\right)_{2}$ was recovered by vacuum filtration and air drying, according to the following chemical reactions:

$$
\mathrm{CaCl}_{2} \cdot \mathrm{xH}_{2} \mathrm{O}+2 \mathrm{NaCl}+2 \mathrm{H}_{3} \mathrm{PO}_{4} \longrightarrow \mathrm{CaNa}_{2}\left(\mathrm{HPO}_{4}\right)_{2}+4 \mathrm{HCl}+\mathrm{xH}_{2} \mathrm{O}
$$

\subsubsection{3. $\mathrm{NaCaPO}_{4}$.}

This compound was prepared by Ben Amara et al. [22] from a stoichiometric mixture of sodium carbonate $\mathrm{NaCO}_{3}$, calcium carbonate $\mathrm{CaCO}_{3}$ and ammonium phosphate $\left(\mathrm{NH}_{4}\right)_{2} \mathrm{HPO}_{4}$, according to the following chemical reactions:

$$
\mathrm{CaCO}_{3}+1 / 2 \mathrm{Na}_{2} \mathrm{CO}_{3}+\left(\mathrm{NH}_{4}\right)_{2} \mathrm{HPO}_{4} \rightarrow \mathrm{NaCaPO}_{4}+3 / 2 \mathrm{CO}_{2}+2 \mathrm{NH}_{3}+3 / 2 \mathrm{H}_{2} \mathrm{O}
$$

The initial mixture was first heated at $673 \mathrm{~K}$ under a nitrogen stream, then at $1223 \mathrm{~K}$ in air. Single crystals of $\mathrm{NaCaPO}_{4}$ were grown by cooling, from 1073 to $473 \mathrm{~K}$ at a rate of $10 \mathrm{Kh}^{-1}$.

\subsection{Crystallographic data.}

\begin{tabular}{|c|c|c|c|c|c|c|c|}
\hline Compound & System & $\begin{array}{l}\text { Space } \\
\text { group }\end{array}$ & $\mathbf{Z}$ & $\begin{array}{c}\mathbf{a}(\AA) \\
\boldsymbol{\alpha}^{\circ}\end{array}$ & $\begin{array}{c}\mathbf{b}(\AA) \\
\boldsymbol{\beta}^{\circ}\end{array}$ & $\begin{array}{c}\mathbf{c}(\mathbf{\AA}) \\
\gamma^{\circ}\end{array}$ & References \\
\hline $\mathrm{Ca}_{10}\left(\mathrm{PO}_{4}\right)_{6} \mathrm{~F}_{2}$ & \multirow{2}{*}{ Hexagonal } & $\mathrm{P}_{3} / \mathrm{m}$ & 1 & 9.364 & 9.364 & 6.893 & [17] \\
\hline $\mathrm{CaZr}_{4}\left(\mathrm{PO}_{4}\right)_{6}$ & & $\mathrm{R}-3$ & & 8.7859 & 8.7852 & 22.6620 & {$[18]$} \\
\hline$\beta \mathrm{Ca}_{3}\left(\mathrm{PO}_{4}\right)_{2}$ & Rhombohedral & $\mathrm{R} 3 \mathrm{c}$ & 21 & 10.4352 & 10.4352 & 37.4029 & [15] \\
\hline
\end{tabular}

In this part, we reported the main crystallographic data for the various monophosphates associated with calcium, classified from the hexagonal to the triclinic system (Table 1). 


\begin{tabular}{|c|c|c|c|c|c|c|c|}
\hline Compound & System & $\begin{array}{l}\text { Space } \\
\text { group }\end{array}$ & $\mathbf{Z}$ & $\begin{array}{c}\mathbf{a}(\AA) \\
\alpha^{\circ}\end{array}$ & $\begin{array}{c}\mathbf{b}(\AA) \\
\boldsymbol{\beta}^{\circ}\end{array}$ & $\begin{array}{c}\mathbf{c}(\AA) \\
\gamma^{\circ}\end{array}$ & References \\
\hline & (hexagonal setting) & & & & & & \\
\hline $\mathrm{CsCa}_{10}\left(\mathrm{PO}_{4}\right)_{7}$ & \multirow{3}{*}{ Trigonal } & R3c & 6 & 10.5536 & 10.5536 & 37.2283 & [19] \\
\hline $\mathrm{Cs}_{0.63 \mathrm{Ca}}{ }_{.63} \mathrm{Fe}_{0.37}\left(\mathrm{PO}_{4}\right)_{7}$ & & R3c & 6 & 10.5221 & 10.5221 & 37.2405 & [19] \\
\hline $\mathrm{Ca} 9 \mathrm{Cr}\left(\mathrm{PO}_{4}\right)_{7}$ & & R3c & 6 & 10.3272 & 10.3272 & 37.132 & {$[20]$} \\
\hline $\mathrm{NaCaPO}_{4}$ & Orthorhombic & Pn21a & 12 & 20.397 & 5.412 & 9.161 & {$[22]$} \\
\hline $\mathrm{CaHPO}_{4} \cdot 2 \mathrm{H}_{2} \mathrm{O}$ & \multirow{4}{*}{ Monoclinic } & $\mathrm{Ia}\left(\mathrm{C}_{\mathrm{s}}^{4}\right)$ & 4 & 5.812 & $\begin{array}{l}15.180 \\
116.25\end{array}$ & 6.239 & {$[12]$} \\
\hline$\alpha \mathrm{Ca}_{3}\left(\mathrm{PO}_{4}\right)_{2}$ & & $\mathrm{P} 2{ }_{1} / \mathrm{a}$ & 24 & 12.887 & $\begin{array}{l}27.280 \\
126.20\end{array}$ & 15.219 & {$[14]$} \\
\hline $\mathrm{Ca}_{4}\left(\mathrm{PO}_{4}\right)_{2} \mathrm{O}$ & & $\mathrm{P} 2{ }_{1}$ & 4 & 7.023 & $\begin{array}{c}11.986 \\
90,90\end{array}$ & 9.473 & {$[16]$} \\
\hline $\mathrm{CaNa}_{2}\left(\mathrm{HPO}_{4}\right)_{2}$ & & $\mathrm{P} 2{ }_{1}$ & 2 & 9.0652 & $\begin{array}{l}7.1468 \\
98.782\end{array}$ & 5.4700 & {$[21]$} \\
\hline $\mathrm{Ca}\left(\mathrm{H}_{2} \mathrm{PO}_{4}\right)_{2} \cdot \mathrm{H}_{2} \mathrm{O}$ & \multirow{3}{*}{ Triclinic } & $\mathrm{P}-1$ & 2 & $\begin{array}{c}5.6125 \\
98.3516\end{array}$ & $\begin{array}{c}11.8821 \\
117.7303\end{array}$ & $\begin{array}{c}6.4324 \\
83.5106\end{array}$ & {$[10]$} \\
\hline $\mathrm{Ca}\left(\mathrm{H}_{2} \mathrm{PO}_{4}\right)_{2}$ & & $\mathrm{P}-1$ & 2 & $\begin{array}{l}7.5577 \\
109.87\end{array}$ & $\begin{array}{c}8.2531 \\
93.68\end{array}$ & $\begin{array}{l}5.5504 \\
109.15\end{array}$ & {$[10,11]$} \\
\hline $\mathrm{CaHPO}_{4}$ & & P-1 & 4 & $\begin{array}{l}6.910 \\
96.34\end{array}$ & $\begin{array}{c}6.627 \\
103.82\end{array}$ & $\begin{array}{l}6.998 \\
88.33\end{array}$ & [13] \\
\hline
\end{tabular}

Table 1. Main crystallographic data for the monophosphates associated with calcium, classified from the hexagonal to the triclinic system.

It is worthy to note that the compounds containing the $\left(\mathrm{PO}_{4}\right)^{3-}$ groups are crystallizing in the hexagonal, rhombohedral, trigonal, orthorhombic, and monoclinic systems, against the compound with $\left(\mathrm{HPO}_{4}\right)^{2-}$ and $\left(\mathrm{H}_{2} \mathrm{PO}_{4}\right)^{-}$, which crystallized in the systems with low symmetry (monoclinic, and triclinic).

\subsection{Infrared characterization studies made on $\mathrm{PO}_{4}{ }^{3-}$ in the monetite, $\mathrm{CaHPO}_{4}$.}

Tortet et al. [23] have studied the infrared spectrum of monetite, $\mathrm{CaHPO}_{4}$ at $25^{\circ} \mathrm{C}$. In this study, the infrared stretching $v(\mathrm{OH})$ observed at 3190,2849 , and $2360 \mathrm{~cm}^{-1}$ was found to be strongly dependent on hydrogen bonding taken place in this compound. The broad band that appeared in 1450-1300 $\mathrm{cm}^{-1}$ was assigned to the $\mathrm{P}-\mathrm{O}-\mathrm{H}$ in-plane bending. The $\mathrm{P}-\mathrm{O}$ and $\mathrm{P}-\mathrm{O}(\mathrm{H})$ stretching of the phosphate $\left[\mathrm{PO}_{4}\right]^{3-}$ anion [24-26] were assigned to the features observed as strong and medium absorptions bands at $1081 \mathrm{~cm}^{-1}$ and $891 \mathrm{~cm}^{-1}$ in the IR spectrum. The O-P-O (H) and O-P-O vibrations of the phosphate $\left[\mathrm{PO}_{4}\right]^{3-}$ anion appeared at $578 \mathrm{~cm}^{-1}$ and $420 \mathrm{~cm}^{-1}$, respectively (Table 2).

Table 2. Frequencies $\left(\mathrm{cm}^{-1}\right)$ of IR absorption bands for monetite, $\mathrm{CaHPO}_{4}$.

\begin{tabular}{|c|c|}
\hline Infrared $\left(v / \mathrm{cm}^{-1}\right)$ & Assignments [23-26] \\
\hline 3447 & $\mathrm{O}-\mathrm{H}$ stretching of residual free water \\
\hline $3190 ; 2849 ; 2360$ & $(\mathrm{P}) \mathrm{O}-\mathrm{H}$ stretching modes \\
\hline $1600-1700$ (broad) & $\begin{array}{c}\mathrm{H}-\mathrm{O}-\mathrm{H} \text { bending and rotation of residual free } \\
\text { water }\end{array}$ \\
\hline $1450-1300$ (broad) & $\mathrm{P}-\mathrm{O}-\mathrm{H}$ in-plane bending \\
\hline $1170 ; 1131 ; 1081$ & $\mathrm{P}-\mathrm{O}$ stretching modes \\
\hline 996 & $\mathrm{P}-\mathrm{O}$ stretching modes \\
\hline 891 & $\mathrm{P}-\mathrm{O}(\mathrm{H})$ stretching \\
\hline 578 & $\mathrm{O}-\mathrm{P}-\mathrm{O}(\mathrm{H})$ \\
\hline 532 & bending modes \\
\hline 420 & $\mathrm{O}-\mathrm{P}-\mathrm{O}$ \\
\hline 404 & bending modes \\
\hline
\end{tabular}




\section{Long polyphosphates chain $\left(\mathrm{PO}_{3}^{-}\right)_{n}$}

\subsection{Synthesis.}

The polyphosphates associated with calcium were prepared by various synthetic methods, such as the conventional solid-state method and thermic method.

\subsection{1. $\quad \mathrm{Ca}\left(\mathrm{PO}_{3}\right)_{2}$}

This compound was prepared by Rothammel et al. [27] by thermal dehydration of the hydrated phase $\mathrm{Ca}\left(\mathrm{H}_{2} \mathrm{PO}_{4}\right)_{2} . \mathrm{H}_{2} \mathrm{O}$ at $1523 \mathrm{~K}$, according to the following chemical reactions:

$$
\mathrm{Ca}\left(\mathrm{H}_{2} \mathrm{PO}_{4}\right)_{2} \cdot \mathrm{H}_{2} \mathrm{O} \rightarrow \mathrm{Ca}\left(\mathrm{PO}_{3}\right)_{2}+3 \mathrm{H}_{2} \mathrm{O}
$$

Cooling of the melt to $1223 \mathrm{~K}$ gives crystals of $\mathrm{Ca}\left(\mathrm{PO}_{3}\right)_{2}$ sufficiently large and high quality.

\subsection{2. $\mathrm{BaCa}\left(\mathrm{PO}_{3}\right)_{4}$.}

This salt was prepared by Averbuch-Pouchot [28] by calcination at $700^{\circ} \mathrm{C}$ of a mixture in stoichiometric proportions of diammonium monophosphate $\left(\mathrm{NH}_{4}\right)_{2} \mathrm{HPO}_{4}$, barium carbonate $\mathrm{BaCO}_{3}$ and calcium carbonate $\mathrm{CaCO}_{3}$, according to the following chemical reactions:

$$
\mathrm{BaCO}_{3}+\mathrm{CaCO}_{3}+4\left(\mathrm{NH}_{4}\right)_{2} \mathrm{HPO}_{4} \rightarrow \mathrm{BaCa}\left(\mathrm{PO}_{3}\right)_{4}+2 \mathrm{CO}_{2}+8 \mathrm{NH}_{3}+6 \mathrm{H}_{2} \mathrm{O}
$$

\subsection{3. $\mathrm{ZnCa}\left(\mathrm{HPO}_{3}\right)_{2} \cdot 2 \mathrm{H}_{2} \mathrm{O}$.}

The titled compound was prepared by Shieh et al. [29], by solution precipitation methods using $\mathrm{ZnCl}, \mathrm{CaHPO}_{3} . \mathrm{H}_{2} \mathrm{O}$, and phosphoric acid $\mathrm{H}_{3} \mathrm{PO}_{4}$ as starting materials. $0.67 \mathrm{~g}$ of $\mathrm{ZnCl}$, was added to a solution of $1.20 \mathrm{~g}$ of $\mathrm{CaHPO}_{3} . \mathrm{H}_{2} \mathrm{O}$ in $10 \mathrm{~mL}$ of aqueous $1 \mathrm{M} \mathrm{H}_{3} \mathrm{PO}_{3}$, according to the following chemical reactions:

$$
\mathrm{ZnCl}_{2}+\mathrm{CaHPO}_{3} \cdot \mathrm{H}_{2} \mathrm{O}+\mathrm{H}_{3} \mathrm{PO}_{4} \rightarrow \mathrm{ZnCa}\left(\mathrm{HPO}_{3}\right)_{2} \cdot 2 \mathrm{H}_{2} \mathrm{O}+2 \mathrm{HCl}
$$

The clear solution was stirred overnight, followed by the addition of $7 \mathrm{~mL}$ of EtOH. Colorless platelike crystals were obtained after the solution had been allowed to stand for several days at room temperature.

\subsection{4. $\mathrm{CaNa}\left(\mathrm{PO}_{3}\right)_{3}$.}

This compound was prepared by Abrahams et al. [30] by the conventional solid-state method. Appropriate stoichiometric amounts of $\mathrm{Na}_{2} \mathrm{CO}_{3}, \mathrm{NH}_{4} \mathrm{H}_{2} \mathrm{PO}_{4}$, and $\mathrm{CaCO}_{3}$ were milled; the dried mixture was placed in a platinum crucible and heated at $300{ }^{\circ} \mathrm{C}$. For 1 hour to decompose the carbonate and then heated for 12 hours at $700{ }^{\circ} \mathrm{C}$, according to the following chemical reactions:

$$
1 / 2 \mathrm{Na}_{2} \mathrm{CO}_{3}+\mathrm{CaCO}_{3}+3 \mathrm{NH}_{4} \mathrm{H}_{2} \mathrm{PO}_{4} \rightarrow \mathrm{CaNa}\left(\mathrm{PO}_{3}\right)_{3}+3 / 2 \mathrm{CO}_{2}+3 \mathrm{NH}_{3}+9 / 2 \mathrm{H}_{2} \mathrm{O}
$$

The crystalline materials of $\mathrm{CaNa}\left(\mathrm{PO}_{3}\right)_{3}$ were obtained by quench quenching to the air.

\subsection{5. $\mathrm{CaHPO}_{3}$.}

Using $\mathrm{Ca}\left(\mathrm{NO}_{3}\right)_{2} .4 \mathrm{H}_{2} \mathrm{O}$ and phosphorous acid $\mathrm{H}_{3} \mathrm{PO}_{3}$ (as starting materials), Phillips et al. [31] have prepared the above-mentioned compound. A mixture of $0.52 \mathrm{~g}$ of $\mathrm{H}_{3} \mathrm{PO}_{3}, 2.36 \mathrm{~g}$ 
of $\mathrm{Ca}\left(\mathrm{NO}_{3}\right)_{2} .4 \mathrm{H}_{2} \mathrm{O}$, and $0.47 \mathrm{~g}$ of $\mathrm{NH}_{4} \mathrm{ClO}_{4}$ was dissolved in $10 \mathrm{ml}$ of $\mathrm{H}_{2} \mathrm{O}$, then mixed with $4.0 \mathrm{~g}$ of $15 \mathrm{~N} \mathrm{NH}_{4} \mathrm{OH}$ and loaded into a $23 \mathrm{ml}$ Teflon cup, according to the following chemical reactions:

$$
\mathrm{Ca}\left(\mathrm{NO}_{3}\right)_{2} \cdot 4 \mathrm{H}_{2} \mathrm{O}+\mathrm{NH}_{4} \mathrm{ClO}_{4}+\mathrm{H}_{3} \mathrm{PO}_{3}+\mathrm{NH}_{4} \mathrm{OH} \longrightarrow \mathrm{CaHPO}_{3}+2 \mathrm{NO} 2+2 \mathrm{NH}_{3}+6 \mathrm{H}_{2} \mathrm{O}+\mathrm{HCl}+7 / 2 \mathrm{O}_{2}
$$

The reaction mixture was heated in a pressure vessel for seven days at $473 \mathrm{~K}$ and cooled to room temperature for a few hours. The product of $\mathrm{CaHPO}_{3}$ was recovered by vacuum filtration and rinsed with deionized water.

\subsection{6. $\mathrm{CaRb}_{2}\left(\mathrm{PO}_{3}\right)_{4}$.}

This crystal was prepared by Henry et al. [32] by calcining of a mixture of equimolecular rubidium $\mathrm{Rb}_{2} \mathrm{CO}_{3}$ and calcium $\mathrm{CaCO}_{3}$ carbonates in a large excess of orthophosphoric acid $\mathrm{H}_{3} \mathrm{PO}_{4}$ at $400^{\circ} \mathrm{C}$ for 24 hours, as the following chemical reactions:

$$
\mathrm{Rb}_{2} \mathrm{CO}_{3}+\mathrm{CaCO}_{3}+4 \mathrm{H}_{3} \mathrm{PO}_{4} \longrightarrow \mathrm{CaRb}_{2}\left(\mathrm{PO}_{3}\right)_{4}+2 \mathrm{CO}_{2}+6 \mathrm{H}_{2} \mathrm{O}
$$

\subsection{7. $\gamma-\mathrm{Ca}\left(\mathrm{PO}_{3}\right)_{2}$.}

This compound was synthesized by Jackson et al. [33] from an acidic flux containing calcium hydroxide $\mathrm{Ca}(\mathrm{OH})_{2}$ and phosphoric acid $\mathrm{H}_{3} \mathrm{PO}_{4}$, according to the following chemical reactions:

$$
\mathrm{Ca}(\mathrm{OH})_{2}+2 \mathrm{H}_{3} \mathrm{PO}_{4} \rightarrow \gamma-\mathrm{Ca}\left(\mathrm{PO}_{3}\right)_{2}+4 \mathrm{H}_{2} \mathrm{O}
$$

The reaction mixture was heated to $250^{\circ} \mathrm{C}$ for 24 hours and allowed to cool. The final products were collected by filtration and washed and then left to dry for $2-3$ hours at $120^{\circ} \mathrm{C}$.

\subsection{8. $\mathrm{LiCa}\left(\mathrm{PO}_{3}\right)_{3}$.}

This crystal was prepared by Han et al. [34] by the conventional solid-state method. Appropriate stoichiometric amounts of $\mathrm{Li}_{2} \mathrm{CO}_{3}, \mathrm{CaCO}_{3}$, and $\mathrm{NH}_{4} \mathrm{H}_{2} \mathrm{PO}_{4}$ were milled; the dried mixture was placed in a platinum crucible and heated at $650{ }^{\circ} \mathrm{C}$ and held at this temperature for $5 \mathrm{~h}$ to obtain a transparent solution, according to the following chemical reactions:

$1 / 2 \mathrm{Li}_{2} \mathrm{CO}_{3}+\mathrm{CaCO}_{3}+3 \mathrm{NH}_{4} \mathrm{H}_{2} \mathrm{PO}_{4} \rightarrow \mathrm{LiCa}\left(\mathrm{PO}_{3}\right)_{3}+3 \mathrm{NH}_{3}+3 / 2 \mathrm{CO}_{2}+9 / 2 \mathrm{H}_{2} \mathrm{O}$

The solution was quickly cooled to $590{ }^{\circ} \mathrm{C}$ and then the temperature lowered to $350{ }^{\circ} \mathrm{C}$ at a rate of $2{ }^{\circ} \mathrm{C} \mathrm{h}^{-1}$. After this process, it was cooled down to room temperature at a rate of $15^{\circ} \mathrm{C} \mathrm{h}^{-1}$. During the slow cooling process, some crystals were obtained.

\subsection{Crystallographic data.}

In this part, we reported the main crystallographic data for the various polyphosphate

\begin{tabular}{|c|c|c|c|c|c|c|c|}
\hline \multicolumn{8}{|c|}{ hexagonal to the triclinic system. } \\
\hline Compound & system & $\begin{array}{l}\text { Space } \\
\text { group }\end{array}$ & $\mathbf{Z}$ & $\begin{array}{c}\mathbf{a}(\mathbf{A}) \\
\boldsymbol{\alpha}^{\circ}\end{array}$ & $\begin{array}{c}\mathbf{b}(\AA) \\
\boldsymbol{\beta}^{\circ}\end{array}$ & $\begin{array}{c}\mathbf{c}(\AA) \\
\gamma^{\circ}\end{array}$ & References \\
\hline $\mathrm{CaHPO}_{3}$ & Tetragonal & $\mathrm{P} 4{ }_{3} 2_{12}$ & 8 & 6.67496 & 6.67496 & 12.9542 & [31] \\
\hline $\mathrm{Ca}\left(\mathrm{PO}_{3}\right)_{2}$ & Monoclinic & $\mathrm{P} 2{ }_{1} / \mathrm{a}$ & 8 & 16.960 & $\begin{array}{l}7.7144 \\
90.394\end{array}$ & 6.9963 & [27] \\
\hline $\mathrm{BaCa}\left(\mathrm{PO}_{3}\right)_{4}$ & & $\mathrm{P} 2{ }_{1} / \mathrm{n}$ & 4 & 15.24 & 9.173 & 7.231 & {$[28]$} \\
\hline
\end{tabular}
associated with calcium, classified from the hexagonal to the triclinic system (Table 3).

Table 3. Main crystallographic data for the polyphosphates associated with calcium, classified from the 


\begin{tabular}{|c|c|c|c|c|c|c|c|}
\hline Compound & system & $\begin{array}{l}\text { Space } \\
\text { group }\end{array}$ & $\mathbf{Z}$ & $\begin{array}{c}\mathbf{a}(\AA) \\
\alpha^{\circ}\end{array}$ & $\begin{array}{c}\mathbf{b}(\AA) \\
\boldsymbol{\beta}^{\circ}\end{array}$ & $\begin{array}{c}\mathbf{c}(\mathbf{A}) \\
\gamma^{\circ}\end{array}$ & References \\
\hline & & & & & 90.96 & & \\
\hline $\mathrm{CaRb}_{2}\left(\mathrm{PO}_{3}\right)_{4}$ & & $\mathrm{P} 21_{1} / \mathrm{n}$ & 4 & 11.436 & $\begin{array}{l}13.352 \\
101.89\end{array}$ & 7.908 & [32] \\
\hline $\mathrm{ZnCa}\left(\mathrm{HPO}_{3}\right)_{2} .2 \mathrm{H}_{2} \mathrm{O}$ & & $\mathrm{P} 2{ }_{1} / \mathrm{n}$ & 4 & 7.131 & $\begin{array}{l}7.766 \\
97.30\end{array}$ & 14.479 & [29] \\
\hline$\gamma \mathrm{Ca}\left(\mathrm{PO}_{3}\right)_{2}$ & & $\mathrm{Cc}$ & 8 & 9.5669 & $\begin{array}{l}9.5023 \\
93.474\end{array}$ & 10.3717 & [33] \\
\hline $\mathrm{CaNa}\left(\mathrm{PO}_{3}\right)_{3}$ & \multirow{2}{*}{ Triclinic } & P-1 & 2 & $\begin{array}{l}6.711 \\
83.44\end{array}$ & $\begin{array}{l}6.934 \\
81.41\end{array}$ & $\begin{array}{l}7.619 \\
82.80\end{array}$ & [30] \\
\hline $\mathrm{LiCa}\left(\mathrm{PO}_{3}\right)_{3}$ & & P-1 & 2 & $\begin{array}{l}6.6726 \\
83.839\end{array}$ & $\begin{array}{l}6.9181 \\
80.595\end{array}$ & $\begin{array}{c}7.334 \\
81.797\end{array}$ & [34] \\
\hline
\end{tabular}

For the long polyphosphates chain $\left(\mathrm{PO}_{3}{ }^{-}\right)_{\mathrm{n}}$, one can state that when the formula contains one $\left(\mathrm{PO}_{4}\right)^{3-}$ group, the corresponding compound is crystallizing in the high symmetry (tetragonal systems), the compounds belonging to the formula with two, three, and four $\left(\mathrm{PO}_{4}\right)^{3-}$ groups are crystallized in the systems with lower symmetry (monoclinic, and triclinic).

\subsection{Infrared characterization studies made on $\mathrm{PO}_{3}{ }_{3}^{-}$in $\gamma-\mathrm{Ca}\left(\mathrm{PO}_{3}\right)$.}

Jackson et al. [33] have studied the infrared spectrum of the sample of $\gamma-\mathrm{Ca}\left(\mathrm{PO}_{3}\right)$ at room temperature. The band in the region of $850-920 \mathrm{~cm}^{-1}$ was assigned to the antisymmetric stretching vibration of the P-O-P, which is at a low frequency due to the infinite number of $\mathrm{PO}_{4}$ units. The band in 1160-1170 $\mathrm{cm}^{-1}$ was assigned to the antisymmetric stretching of the terminal $\mathrm{PO}_{3}$, and the band at $1230-1250 \mathrm{~cm}^{-1}$ to the antisymmetric stretching vibration of the bridging $\mathrm{PO}_{2}$. The symmetric stretching bridging $\mathrm{PO}_{2}$ was assigned to the band in 1080-1110 $\mathrm{cm}^{-1}$, and the symmetric $\mathrm{PO}_{3}$ stretching modes appeared in 940-1020 $\mathrm{cm}^{-1}$ (Table 4).

Table 4. Frequencies $\left(\mathrm{cm}^{-1}\right)$ of IR absorption bands for $\gamma-\mathrm{Ca}\left(\mathrm{PO}_{3}\right)_{2}$.

\begin{tabular}{c|c} 
Frequencies $\left(\boldsymbol{v} / \mathbf{c m}^{-1}\right)$ & Assignments[33] \\
\hline $1230-1250$ & $v_{\mathrm{as}}\left(\mathrm{PO}_{2}\right)$ \\
\hline $1160-1170$ & $v_{\mathrm{as}}\left(\mathrm{PO}_{3}\right)$ \\
\hline $1080-1110$ & $\mathrm{v}_{\mathrm{s}}\left(\mathrm{PO}_{2}\right)$ \\
\hline $940-1020$ & $\mathrm{v}_{\mathrm{s}}\left(\mathrm{PO}_{3}\right)$ \\
\hline $850-920$ & $v_{\mathrm{as}}(\mathrm{P}-\mathrm{O}-\mathrm{P})$
\end{tabular}

\section{Condensed phosphates}

\subsection{Oligophosphates $\left(P_{n} O_{3 n+1}\right)^{(n+2)}$.}

\subsubsection{Diphosphates $\mathrm{P}_{2} \mathrm{O}_{7}{ }^{4-}$.}

\subsubsection{Synthesis.}

In this part, we present the synthesis of the diphosphates associated with calcium by the various synthetic methods: thermic method and co-precipitation method.

\subsubsection{1. $\mathrm{CaCuP}_{2} \mathrm{O}_{7}$.}

This compound was prepared by Riou et al. [35], from a mixture of copper oxide $\mathrm{CuO}$, calcium carbonate $\mathrm{CaCO}_{3}$ and diammonium phosphate $\left(\mathrm{NH}_{4}\right)_{2} \mathrm{HPO}_{4}$ in ratios $1: 1: 2$, as the following chemical reaction: 


\section{$\mathrm{CuO}+\mathrm{CaCO}_{3}+2\left(\mathrm{NH}_{4}\right)_{2} \mathrm{HPO}_{4} \rightarrow \mathrm{CaCuP}_{2} \mathrm{O}_{7}+\mathrm{CO}_{2}+4 \mathrm{NH}_{3}+3 \mathrm{H}_{2} \mathrm{O}$}

The reaction mixture was first heated at $973 \mathrm{~K}$ to decompose the carbonate and the phosphate. The resultant product was ground and heated for nine days at $1333 \mathrm{~K}$. The quenching at room temperature gives crystals of $\mathrm{CaCuP}_{2} \mathrm{O}_{7}$ sufficiently large and high quality

\subsubsection{2. $\quad \mathrm{Ca}_{3}\left(\mathrm{NH}_{4}\right)_{2}\left(\mathrm{P}_{2} \mathrm{O}_{7}\right)_{2} \cdot 6 \mathrm{H}_{2} \mathrm{O}$.}

This crystal was prepared by Brown et al. [36] by mixing 1 gram of $\mathrm{Ca}_{3} \mathrm{H}_{2}\left(\mathrm{P}_{2} \mathrm{O}_{7}\right)_{2} .4 \mathrm{H}_{2} \mathrm{O}$ and $15 \mathrm{ml}$ of $\mathrm{NH}_{4} \mathrm{OH}(\mathrm{O} .6 \mathrm{M})$ at room temperature for 24 to 48 hours, according to the following chemical reaction:

$$
\mathrm{Ca}_{3} \mathrm{H}_{2}\left(\mathrm{P}_{2} \mathrm{O}_{7}\right)_{2} .4 \mathrm{H}_{2} \mathrm{O}+2 \mathrm{NH}_{4} \mathrm{OH} \longrightarrow \mathrm{Ca}_{3}\left(\mathrm{NH}_{4}\right)_{2}\left(\mathrm{P}_{2} \mathrm{O}_{7}\right)_{2} .6 \mathrm{H}_{2} \mathrm{O}
$$

\subsubsection{3. $\mathrm{Ca}_{5} \mathrm{M}_{2}\left(\mathrm{P}_{2} \mathrm{O}_{7}\right)_{3} \cdot 6 \mathrm{H}_{2} \mathrm{O}(\mathrm{M}=\mathrm{NH} 4, \mathrm{~K})$.}

These two salts were prepared by Brown et al. [36] by adding 1 gram of $\mathrm{Ca}_{2} \mathrm{P}_{2} \mathrm{O}_{7} .4 \mathrm{H}_{2} \mathrm{O}$ calcium pyrophosphate (prepared from $\mathrm{Na}_{4} \mathrm{P}_{2} \mathrm{O}_{7}$ and $\left.\mathrm{CaCl}_{2}\right)$ to a stirred $\left(5 \mathrm{M} \mathrm{NH}_{4} \mathrm{Cl}\right.$ or $\left.5 \mathrm{M} \mathrm{KCl}\right)$ solution at $70^{\circ}$ to $75^{\circ} \mathrm{C}$, according to the following chemical reaction:

$$
\begin{aligned}
\mathrm{Na}_{4} \mathrm{P}_{2} \mathrm{O}_{7} .4 \mathrm{H}_{2} \mathrm{O}+2 \mathrm{CaCl}_{2} & \rightarrow \mathrm{Ca}_{2} \mathrm{P}_{2} \mathrm{O}_{7} .4 \mathrm{H}_{2} \mathrm{O}+4 \mathrm{NaCl} \\
3 \mathrm{Ca}_{2} \mathrm{P}_{2} \mathrm{O}_{7} .4 \mathrm{H}_{2} \mathrm{O}+2 \mathrm{MCl}+2 \mathrm{H}_{2} \mathrm{O} & \longrightarrow \mathrm{Ca}_{5} \mathrm{M}_{2}\left(\mathrm{P}_{2} \mathrm{O}_{7}\right)_{3} .6 \mathrm{H}_{2} \mathrm{O}+\mathrm{CaCl}_{2}
\end{aligned}
$$

The products precipitated rapidly. Larger crystals were prepared by allowing a diluted mixture of the reagents to stand at room temperature for about a week.

\subsubsection{4. $\quad \mathrm{Ca}\left(\mathrm{NH}_{4}\right)_{2} \mathrm{H}_{4}\left(\mathrm{P}_{2} \mathrm{O}_{7}\right)_{2}$.}

Brown et al. [36] have also prepared the $\mathrm{Ca}\left(\mathrm{NH}_{4}\right)_{2} \mathrm{H}_{4}\left(\mathrm{P}_{2} \mathrm{O}_{7}\right)_{2}$ compound by allowing 5 grams of $\mathrm{CaH}_{2} \mathrm{P}_{2} \mathrm{O}_{7}$ to stand at room temperature in $20 \mathrm{ml}$ of a saturated solution of $\mathrm{NH}_{4} \mathrm{Cl}$ for about 24 hours, according to the following chemical reaction:

$$
2 \mathrm{CaH}_{2} \mathrm{P}_{2} \mathrm{O}_{7}+2 \mathrm{NH} 4 \mathrm{Cl} \rightarrow \mathrm{Ca}\left(\mathrm{NH}_{4}\right)_{2} \mathrm{H}_{4}\left(\mathrm{P}_{2} \mathrm{O}_{7}\right)_{2}+\mathrm{CaCl}_{2}
$$

The product was filtered by suction, suspended in ethyl alcohol to remove $\mathrm{NH}_{4} \mathrm{Cl}$, filtered, rinsed with acetone, and air-dried.

\subsubsection{5. $\mathrm{CaK}_{2} \mathrm{H}_{4}\left(\mathrm{P}_{2} \mathrm{O}_{7}\right)_{2}$.}

This salt was prepared by Brown et al. [36] by adding 5 grams of $\mathrm{CaH}_{2} \mathrm{P}_{2} \mathrm{O}_{7}$ to a mixture of $20 \mathrm{ml}$ of saturated $\mathrm{KCl}$ solution and 10 grams of solid $\mathrm{KCl}$ and allowing the mixture to stand at room temperature for 12 to 24 hours, according to the following chemical reaction:

$$
2 \mathrm{CaH}_{2} \mathrm{P}_{2} \mathrm{O}_{7}+2 \mathrm{KCl} \rightarrow \mathrm{CaK}_{2} \mathrm{H}_{4}\left(\mathrm{P}_{2} \mathrm{O}_{7}\right)_{2}+\mathrm{CaCl}_{2}
$$

The product was filtered rapidly by suction, suspended in ethyl alcohol to remove $\mathrm{KCl}$, filtered, rinsed with acetone, and air-dried.

\subsubsection{6. $\quad \mathrm{CaNH}_{4} \mathrm{HP}_{2} \mathrm{O}_{7}$}

This salt was prepared by Mathew et al. [37] by adding $1 \mathrm{~g}$ of $\mathrm{CaH}_{2} \mathrm{P}_{2} \mathrm{O}_{7}$ to a solution of $2.4 \mathrm{~g}$ of $\mathrm{NH}_{4} \mathrm{Cl}$ in $75 \mathrm{ml}$ of $\mathrm{H}_{2} \mathrm{O}$ at $65^{\circ} \mathrm{C}$, according to the following chemical reaction: 


\section{$\mathrm{CaH}_{2} \mathrm{P}_{2} \mathrm{O}_{7}+\mathrm{NH}_{4} \mathrm{Cl} \longrightarrow \mathrm{CaNH}_{4} \mathrm{HP}_{2} \mathrm{O}_{7}+\mathrm{HCl}$}

The solution was allowed to cool to $52{ }^{\circ} \mathrm{C}$ over a period of a few hours without stirring. The solution was then held at that temperature overnight to encourage the growth of the title compound.

\subsubsection{7. $\mathrm{CaK}_{2} \mathrm{P}_{2} \mathrm{O}_{7}$.}

This phase was prepared by Sandström et al. [38] by mixing potassium carbonate $\mathrm{K}_{2} \mathrm{CO}_{3}$ and calcium polyphosphate $\mathrm{Ca}\left(\mathrm{PO}_{3}\right)_{2}$ at $1273 \mathrm{~K}$ in a $1: 1$ ratio, as illustrated by the following chemical reaction:

$$
\mathrm{Ca}\left(\mathrm{PO}_{3}\right)_{2}+\mathrm{K}_{2} \mathrm{CO}_{3} \longrightarrow \mathrm{CaK}_{2} \mathrm{P}_{2} \mathrm{O}_{7}+\mathrm{CO}_{2}
$$

Crystals of $\mathrm{CaK}_{2} \mathrm{P}_{2} \mathrm{O}_{7}$ were grown by heating a mixture consisting of $\mathrm{CaK}_{2} \mathrm{P}_{2} \mathrm{O}_{7}$ and $\mathrm{KH}_{2} \mathrm{PO}_{4}$ at $1323 \mathrm{~K}$ for about $12 \mathrm{~h}$, followed by cooling at $1023 \mathrm{~K}$, and finally quenching to room temperature. The solidified liquid was crushed, and the resulting colorless crystals were picked out.

\subsubsection{8. $\mathrm{CaNH}_{4} \mathrm{NaP}_{2} \mathrm{O}_{7} .3 \mathrm{H}_{2} \mathrm{O}$.}

This compound was obtained by Averbuch-Pouchot et al. [39] by adding a dilute solution of calcium chloride $\mathrm{CaCl}_{2}$ to a concentrated solution of ammonium chloride $\mathrm{NH}_{4} \mathrm{Cl}$ and sodium diphosphate $\mathrm{Na}_{2} \mathrm{P}_{2} \mathrm{O}_{7}$, which causes the formation of a gel that gradually transforms at room temperature, giving rise to crystals of $\mathrm{CaNH}_{4} \mathrm{NaP}_{2} \mathrm{O}_{7} .3 \mathrm{H}_{2} \mathrm{O}$ sufficiently strong and good quality, according to the following chemical reaction:

$$
\mathrm{CaCl}_{2}+\mathrm{NH}_{4} \mathrm{Cl}+\mathrm{Na}_{2} \mathrm{P}_{2} \mathrm{O}_{7} \rightarrow \mathrm{CaNH}_{4} \mathrm{NaP}_{2} \mathrm{O}_{7} \cdot 3 \mathrm{H}_{2} \mathrm{O}+\mathrm{NaCl}
$$

4.1.1.1.9. $\alpha-\mathrm{CaNa}_{2} \mathrm{P}_{2} \mathrm{O}_{7} .4 \mathrm{H}_{2} \mathrm{O}$ and $\beta-\mathrm{CaNa}_{2} \mathrm{P}_{2} \mathrm{O}_{7} .4 \mathrm{H}_{2} \mathrm{O}$.

The two crystal forms were prepared by Cheng et al. [40] by adding $0.1 \mathrm{M}$ $\mathrm{Na}_{4} \mathrm{P}_{2} \mathrm{O}_{7} .10 \mathrm{H}_{2} \mathrm{O}$ first neutralized with hydrochloric acid $\mathrm{HCl}$ to $1 \mathrm{mM} \mathrm{CaCl} 2$ at room temperature, according to the following chemical reaction:

$$
\mathrm{CaC}_{12}+\mathrm{Na}_{4} \mathrm{P}_{2} \mathrm{O}_{7} .10 \mathrm{H}_{2} \mathrm{O} \rightarrow \mathrm{CaNa}_{2} \mathrm{P}_{2} \mathrm{O}_{7} .4 \mathrm{H}_{2} \mathrm{O}+2 \mathrm{NaCl}+6 \mathrm{H}_{2} \mathrm{O}
$$

\subsection{0. $\quad \beta \mathrm{Ca}_{2} \mathrm{P}_{2} \mathrm{O}_{7}$.}

This compound was obtained by Webb et al. [41,42] by heating the dicalcium phosphate dehydrate $\mathrm{CaHPO}_{4} \cdot 2 \mathrm{H}_{2} \mathrm{O}$ to approximately $750^{\circ} \mathrm{C}$ produces $\beta-\mathrm{Ca}_{2} \mathrm{P}_{2} \mathrm{O}_{7}$, as illustrated in the following chemical reaction:

\subsection{1. $\mathrm{Cs}_{3} \mathrm{CaBi}\left(\mathrm{P}_{2} \mathrm{O}_{7}\right)_{2}$.}

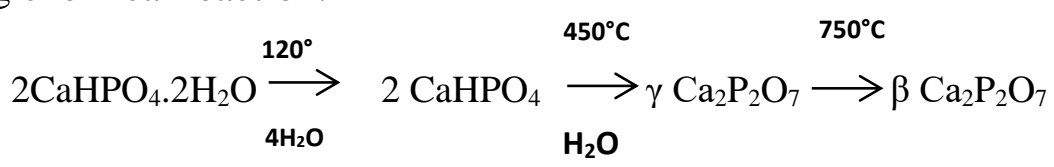

This compound was obtained by Zatovsky et al. [43] using the conventional solid-state method. Appropriate stoichiometric amounts of bismuth oxide $\mathrm{Bi}_{2} \mathrm{O}_{3}$, calcium $\mathrm{CaCO}_{3}$, dihydrogen phosphate $\mathrm{CsH}_{2} \mathrm{PO}_{4}$ and diammonium phosphate $\left(\mathrm{NH}_{4}\right)_{2} \mathrm{HPO}_{4}$ were ground and then heated to $1273 \mathrm{~K}$, according to the following chemical reaction: 
$\mathrm{CsH}_{2} \mathrm{PO}_{4}+2 \mathrm{CsOH} \cdot \mathrm{H}_{2} \mathrm{O}+3(\mathrm{NH} 4)_{2} \mathrm{HPO}_{4}+1 / 2 \mathrm{Bi}_{2} \mathrm{O}_{3}+\mathrm{CaCO}_{3} \rightarrow \mathrm{Cs}_{3} \mathrm{CaBi}_{2}\left(\mathrm{P}_{2} \mathrm{O}_{7}\right)_{2}+\mathrm{CO}_{2}+17 / 2 \mathrm{H}_{2} \mathrm{O}+6 \mathrm{NH}_{3}$

The molten product was maintained at this temperature for 1 hour, cooled with a speed of $25 \mathrm{Kh}^{-1}$ to $973 \mathrm{~K}$, and then cooled to room temperature. The crystals $\mathrm{Cs}_{3} \mathrm{CaBi}\left(\mathrm{P}_{2} \mathrm{O}_{7}\right)_{2}$ were separated from the glass by washing with distilled water and air.

\subsection{2. $\mathrm{CaRb}_{2} \mathrm{P}_{2} \mathrm{O}_{7}$ and $\mathrm{CaCs}_{2} \mathrm{P}_{2} \mathrm{O}_{7}$.}

These two compounds were prepared by Lyutsko et al. [44] by heating a mixture of calcium dihydrogen diphosphate $\mathrm{CaH}_{2} \mathrm{P}_{2} \mathrm{O}_{7}$ and $\left.\mathrm{M}^{\mathrm{I} N O} \mathrm{NO}_{3}{ }^{\mathrm{I}}=\mathrm{Rb}, \mathrm{Cs}\right)$ at $1073 \mathrm{~K}$, according to the following chemical reaction:

$$
\mathrm{CaH}_{2} \mathrm{P}_{2} \mathrm{O}_{7}+2 \mathrm{MNO}_{3}(\mathrm{M}: \mathrm{Rb}, \mathrm{Cs}) \rightarrow \mathrm{CaM}_{2} \mathrm{P}_{2} \mathrm{O}_{7}(\mathrm{M}: \mathrm{Rb}, \mathrm{Cs})+2 \mathrm{NO}_{2}+\mathrm{H}_{2} \mathrm{O}
$$

\subsubsection{Crystallographic data.}

The main crystallographic data are reviewed for the various diphosphates associated with calcium and classified from the hexagonal to the monoclinic system (Table 5).

Table 5. Main crystallographic data for the diphosphates associated with calcium, classified from the hexagonal

\begin{tabular}{|c|c|c|c|c|c|c|c|}
\hline Compound & System & Space group & $\mathbf{Z}$ & $\begin{array}{l}\mathbf{a}(\mathbf{\AA}) \\
\boldsymbol{\alpha}^{\circ}\end{array}$ & $\begin{array}{l}\mathbf{b}(\AA) \\
\boldsymbol{\beta}^{\circ}\end{array}$ & $\begin{array}{l}\mathbf{c}(\mathbf{\AA}) \\
\gamma^{\circ}\end{array}$ & References \\
\hline $\mathrm{Ca}_{5}\left(\mathrm{NH}_{4}\right)_{2}\left(\mathrm{P}_{2} \mathrm{O}_{7}\right)_{3} \cdot 6 \mathrm{H}_{2} \mathrm{O}$ & \multirow{2}{*}{ Hexagonal } & 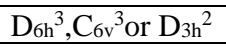 & 2 & 11.88 & 11.88 & 9.83 & {$[36]$} \\
\hline $\mathrm{Ca}_{5} \mathrm{~K}_{2}\left(\mathrm{P}_{2} \mathrm{O}_{7}\right)_{3} \cdot 6 \mathrm{H}_{2} \mathrm{O}$ & & 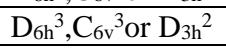 & 2 & 11.88 & 11.88 & 9.83 & [36] \\
\hline$\beta-\mathrm{Ca}_{2} \mathrm{P}_{2} \mathrm{O}_{7}$ & Tetragonal & $\mathrm{P} 4_{1}$ & 8 & 6.684 & 6.684 & 24.144 & {$[41,42]$} \\
\hline $\mathrm{Cs}_{3} \mathrm{CaBi}\left(\mathrm{P}_{2} \mathrm{O}_{7}\right)_{2}$ & Orthorhombic & $\mathrm{P} 22_{1} 2_{1}$ & 4 & 9.2873 & 9.4292 & 17.6162 & [43] \\
\hline $\mathrm{CaCuP}_{2} \mathrm{O}_{7}$ & \multirow{11}{*}{ Monoclinic } & $\mathrm{P} 21 / \mathrm{n}$ & 4 & 5.2104 & $\begin{array}{l}8.0574 \\
91.356 \\
\end{array}$ & 12.344 & {$[35]$} \\
\hline $\mathrm{Ca}_{3}\left(\mathrm{NH}_{4}\right)_{2}\left(\mathrm{P}_{2} \mathrm{O}_{7}\right)_{2} \cdot 6 \mathrm{H}_{2} \mathrm{O}$ & & $\mathrm{P} 2{ }_{1} / \mathrm{n}$ & 2 & 7.67 & $\begin{array}{l}11.51 \\
92.28\end{array}$ & 11.00 & {$[36]$} \\
\hline $\mathrm{Ca}\left(\mathrm{NH}_{4}\right)_{2} \mathrm{H}_{4}\left(\mathrm{P}_{2} \mathrm{O}_{7}\right)_{2}$ & & $\mathrm{C} 2 / \mathrm{c}$ & 4 & 7.17 & $\begin{array}{l}19.99 \\
102.52\end{array}$ & 9.33 & {$[36]$} \\
\hline $\mathrm{CaK}_{2} \mathrm{H}_{4}\left(\mathrm{P}_{2} \mathrm{O}_{7}\right)_{2}$ & & $\mathrm{C} 2 / \mathrm{c}$ & 4 & 7.17 & $\begin{array}{l}19.99 \\
102.52\end{array}$ & 9.33 & {$[36]$} \\
\hline $\mathrm{CaNH}_{4} \mathrm{HP}_{2} \mathrm{O}_{7}$ & & $\mathrm{P} 2{ }_{1} / \mathrm{n}$ & 8 & 10.523 & $\begin{array}{l}17.672 \\
90.47 \\
\end{array}$ & 7.266 & {$[36,37]$} \\
\hline $\mathrm{CaK}_{2} \mathrm{P}_{2} \mathrm{O}_{7}$ & & $\mathrm{P} 21 / \mathrm{n}$ & 4 & 9.79 & $\begin{array}{l}5.69 \\
104.03 \\
\end{array}$ & 12.97 & {$[38]$} \\
\hline $\mathrm{CaNH}_{4} \mathrm{NaP}_{2} \mathrm{O}_{7} .3 \mathrm{H}_{2} \mathrm{O}$ & & $\mathrm{Cc}$ & 4 & 10.39 & $\begin{array}{l}16.55 \\
103.31\end{array}$ & 5.677 & [39] \\
\hline$\alpha \mathrm{CaNa}_{2} \mathrm{P}_{2} \mathrm{O}_{7} .4 \mathrm{H}_{2} \mathrm{O}$ & & $\mathrm{Pc}$ & 2 & 5.689 & $\begin{array}{l}8.586 \\
106.3\end{array}$ & 10.565 & {$[40]$} \\
\hline$\beta \mathrm{CaNa}_{2} \mathrm{P}_{2} \mathrm{O}_{7} .4 \mathrm{H}_{2} \mathrm{O}$ & & $\mathrm{Cc}$ & 4 & 10.380 & $\begin{array}{l}16.980 \\
104.4\end{array}$ & 5.750 & {$[40]$} \\
\hline $\mathrm{CaRb}_{2} \mathrm{P}_{2} \mathrm{O}_{7}$ & & $\mathrm{P} 2{ }_{1} / \mathrm{n}$ & 4 & 10.012 & $\begin{array}{l}5.784 \\
104.79\end{array}$ & 13.070 & [44] \\
\hline $\mathrm{CaCs}_{2} \mathrm{P}_{2} \mathrm{O}_{7}$ & & $\mathrm{P} 2{ }_{1} / \mathrm{n}$ & 4 & 10.302 & $\begin{array}{l}5.946 \\
104.73\end{array}$ & 13.182 & [44] \\
\hline
\end{tabular}

4.1.1.3. Infrared characterization studies made on $\mathrm{P}_{2} \mathrm{O}_{7}{ }^{4-}$ in $\beta-\mathrm{Ca}_{2} \mathrm{P}_{2} \mathrm{O}_{7}$.

De Waal et al. [45] have studied the infrared spectrum of $\beta-\mathrm{Ca}_{2} \mathrm{P}_{2} \mathrm{O}_{7}$ at room temperature. The spectral stretching region between 1400 and $1000 \mathrm{~cm}^{-1}$ contains several peaks. The P-O-P symmetrical stretching modes were identified unambiguously at $725 \mathrm{~cm}^{-1}$ [45-50]. Because of the low intensity of modes in the bending region of the infrared spectra, the assignment is not clearly defined as in the case of stretching modes. The P-O-P asymmetrical stretching is identified at $972 \mathrm{~cm}^{-1}$. In the interval 
1211-1003 $\mathrm{cm}^{-1}$, it was observed the $\mathrm{PO}_{3}$ symmetrical and asymmetrical stretching modes (Table 6).

Table 6. Frequencies $\left(\mathrm{cm}^{-1}\right)$ of IR absorption bands for $\beta-\mathrm{Ca}_{2} \mathrm{P}_{2} \mathrm{O}_{7}$.

\begin{tabular}{c|c} 
Frequencies $\left(\mathbf{v} / \mathbf{c m}^{-\mathbf{1}}\right)$ & Assignment $[45-50]$ \\
\hline $1211 ; 1188 ; 1172 ; 1157 ;$ & $v_{\text {as }}\left(\mathrm{PO}_{3}\right)$ \\
\hline $1138 ; 1102 ; 1086 ; 1078$ & $v_{\mathrm{s}}\left(\mathrm{PO}_{3}\right)$ \\
\hline $1062 ; 1046 ; 1028 ; 1003$ & $v_{\mathrm{as}}(\mathrm{POP})$ \\
\hline $972 ; 943 ; 916$ & $v_{\mathrm{s}}(\mathrm{POP})$
\end{tabular}

\subsection{Cyclophosphates.}

\subsubsection{Cyclotriphosphates $\mathrm{P}_{3} \mathrm{O}_{9}{ }^{3-}$.}

\subsubsection{Synhesis.}

We present here the synthesis of the cyclotriphosphates associated with calcium by the various synthetic methods: ion-exchange resin and thermic method.

\subsubsection{1. $\quad \mathrm{Ca}_{3}\left(\mathrm{P}_{3} \mathrm{O}_{9}\right)_{2} \cdot 10 \mathrm{H}_{2} \mathrm{O}$.}

This compound was prepared by Belaaouad et al. [51] by adding dilute cyclotriphosphoric acid $\mathrm{H}_{3} \mathrm{P}_{3} \mathrm{O}_{9}(0.67 \mathrm{~mol} / \mathrm{l})$ slowly to an aqueous solution of calcium carbonate $\mathrm{CaCO}_{3}(1 \mathrm{~mol} / \mathrm{l})$, according to the following chemical reaction during 24 hours of mechanical stirring:

$$
2 \mathrm{H}_{3} \mathrm{P}_{3} \mathrm{O}_{9}+3 \mathrm{CaCO}_{3}+7 \mathrm{H}_{2} \mathrm{O} \longrightarrow \mathrm{Ca}_{3}\left(\mathrm{P}_{3} \mathrm{O}_{9}\right)_{2} \cdot 10 \mathrm{H}_{2} \mathrm{O}+3 \mathrm{CO}_{2}
$$

The obtained solution was then slowly evaporated at $25^{\circ} \mathrm{C}$, until polycrystalline samples of $\mathrm{Ca}_{3}\left(\mathrm{P}_{3} \mathrm{O}_{9}\right)_{2} .10 \mathrm{H}_{2} \mathrm{O}$ were obtained after 35 days. The $\mathrm{H}_{3} \mathrm{P}_{3} \mathrm{O}_{9}$ used in this reaction was prepared from an aqueous solution of $\mathrm{Na}_{3} \mathrm{P}_{3} \mathrm{O}_{9}$ passed through an ion-exchange resin.

\subsubsection{2. $\quad \mathrm{MnCa}_{2}\left(\mathrm{P}_{3} \mathrm{O}_{9}\right)_{2} \cdot 10 \mathrm{H}_{2} \mathrm{O}$.}

Tridane et al. [52,53], have prepared the titled compound by slowly adding diluted cyclotriphosphoric acid $\mathrm{H}_{3} \mathrm{P}_{3} \mathrm{O}_{9}$ to an aqueous solution of calcium carbonate $\mathrm{CaCO}_{3}$ and manganese carbonate $\mathrm{MnCO}_{3}$ with a stoichiometric ratio $\mathrm{Ca} / \mathrm{Mn}=2$, according to the following chemical reaction:

$$
2 \mathrm{H}_{3} \mathrm{P}_{3} \mathrm{O}_{9}+2 \mathrm{CaCO}_{3}+\mathrm{MnCO}_{3}+7 \mathrm{H}_{2} \mathrm{O} \longrightarrow \mathrm{MnCa}_{2}\left(\mathrm{P}_{3} \mathrm{O}_{9}\right)_{2} \cdot 10 \mathrm{H}_{2} \mathrm{O}+3 \mathrm{CO}_{2}
$$

The obtained solution was then slowly evaporated at room temperature until large rectangular prisms of $\mathrm{MnCa}_{2}\left(\mathrm{P}_{3} \mathrm{O}_{9}\right)_{2} \cdot 10 \mathrm{H}_{2} \mathrm{O}$ are obtained.

\subsubsection{3. $\quad \mathrm{MnCa}_{2}\left(\mathrm{P}_{3} \mathrm{O}_{9}\right)_{2}$.}

The anhydrous form has also been obtained by Tridane et al. [52,53] by total dehydration of $\mathrm{MnCa}_{2}\left(\mathrm{P}_{3} \mathrm{O}_{9}\right)_{2} \cdot 10 \mathrm{H}_{2} \mathrm{O}$ under atmospheric pressure between 400 and $450^{\circ} \mathrm{C}$, as the following chemical reaction:

$$
\mathrm{MnCa}_{2}\left(\mathrm{P}_{3} \mathrm{O}_{9}\right)_{2} \cdot 10 \mathrm{H}_{2} \mathrm{O} \longrightarrow \mathrm{MnCa}_{2}\left(\mathrm{P}_{3} \mathrm{O}_{9}\right)_{2}+10 \mathrm{H}_{2} \mathrm{O}
$$




\subsubsection{4. $\mathrm{CsCaP}_{3} \mathrm{O}_{9}$.}

This compound was obtained by Zatovsky et al. [54] by the conventional solid-state method. Using diammonium hydrogen phosphate $\left(\mathrm{NH}_{4}\right)_{2} \mathrm{HPO}_{4}, \mathrm{CsPO}_{3}$, and $\mathrm{CaHPO}_{4}$ as starting materials. A mixture of $2.11 \mathrm{~g}$ of $\left(\mathrm{NH}_{4}\right)_{2} \mathrm{HPO}_{4}, 5 \mathrm{~g}$ of $\mathrm{CsPO}_{3}$, and $0.952 \mathrm{~g}$ of $\mathrm{CaHPO}_{4}$ was ground and then heated to $973 \mathrm{~K}$ for $3 \mathrm{~h}$, according to the following chemical reaction:

$$
\mathrm{CaHPO}_{4}+\mathrm{CsPO}_{3}+\left(\mathrm{NH}_{4}\right)_{2} \mathrm{HPO}_{4} \longrightarrow \mathrm{CsCaP}_{3} \mathrm{O}_{9}+2 \mathrm{NH}_{3}+2 \mathrm{H}_{2} \mathrm{O}
$$

The resulting melt was kept at this temperature for $30 \mathrm{~min}$ and finally cooled to room temperature. Crystals of $\mathrm{CsCaP}_{3} \mathrm{O}_{9}$ were separated from the rest of the glassy matrix by washing with hot deionized water.

\subsubsection{5. $\mathrm{CaRbP}_{3} \mathrm{O}_{9}$.}

This compound has been obtained by Henry et al. [32] from a mixture of calcium carbonate $\mathrm{CaCO}_{3}$, rubidium carbonate $\mathrm{RbCO}_{3}$, and diammonium hydrogen phosphate $\left(\mathrm{NH}_{4}\right)_{2} \mathrm{HPO}_{4}$ at $400^{\circ} \mathrm{Cfor}$ one week, according to the following chemical reaction:

$$
\mathrm{CaCO}_{3}+1 / 2 \mathrm{Rb}_{2} \mathrm{CO}_{3}+3\left(\mathrm{NH}_{4}\right)_{2} \mathrm{HPO}_{4} \longrightarrow \mathrm{CaRbP}_{3} \mathrm{O}_{9}+6 \mathrm{NH}_{3}+3 / 2 \mathrm{CO}_{2}+9 / 2 \mathrm{H}_{2} \mathrm{O}
$$

\subsubsection{6. $\quad \mathrm{CaNH}_{4} \mathrm{P}_{3} \mathrm{O}_{9}$.}

This compound was prepared by Masse et al. [55,56], from a mixture of calcium carbonate $\mathrm{CaCO}_{3}$, and diammonium hydrogen phosphate $\left(\mathrm{NH}_{4}\right)_{2} \mathrm{HPO}_{4}$ at $300^{\circ} \mathrm{C}$, according to the following chemical reaction:

$$
\mathrm{CaCO}_{3}+3\left(\mathrm{NH}_{4}\right)_{2} \mathrm{HPO}_{4} \longrightarrow \mathrm{CaNH}_{4} \mathrm{P}_{3} \mathrm{O}_{9}+5 \mathrm{NH}_{3}+\mathrm{CO}_{2}+4 \mathrm{H}_{2} \mathrm{O}
$$

\subsubsection{7. $\quad \mathrm{CaNH}_{4} \mathrm{P}_{3} \mathrm{O}_{9} \cdot 3 \mathrm{H}_{2} \mathrm{O}$.}

The silt was obtained by Masse et al. $[55,56]$ by the Boullé method. $\mathrm{Ag}_{3} \mathrm{P}_{3} \mathrm{O}_{9}$ was mixed with a solution of calcium chloride $\mathrm{CaCl}_{2}$ and ammonium chloride $\mathrm{NH}_{4} \mathrm{Cl}$ in stoichiometric proportions, according to the following chemical reaction:

$$
\mathrm{CaCl}_{2}+\mathrm{NH}_{4} \mathrm{Cl}+\mathrm{Ag}_{3} \mathrm{P}_{3} \mathrm{O}_{9}+3 \mathrm{H}_{2} \mathrm{O} \longrightarrow \mathrm{CaNH}_{4} \mathrm{P}_{3} \mathrm{O}_{9} .3 \mathrm{H}_{2} \mathrm{O}+3 \mathrm{AgCl}
$$

The obtained solution was then slowly evaporated at room temperature; crystals of $\mathrm{CaNH}_{4} \mathrm{P}_{3} \mathrm{O}_{9} .3 \mathrm{H}_{2} \mathrm{Osufficiently} \mathrm{strong} \mathrm{and} \mathrm{good} \mathrm{qualities} \mathrm{were} \mathrm{obtained.}$

\subsubsection{8. $\quad \mathrm{CaKP}_{3} \mathrm{O}_{9}$.}

This compound has prepared by Sandström et al. [57] by mixing $\mathrm{Ca}\left(\mathrm{PO}_{3}\right)_{2}$ (obtained from dehydrated of $\mathrm{Ca}\left(\mathrm{H}_{2} \mathrm{PO}_{4}\right)_{2}$ at $873 \mathrm{~K}$ ) and $\mathrm{KPO}_{3}$ (obtained from dehydrated of $\mathrm{KH}_{2} \mathrm{PO}_{4}$ at $873 \mathrm{~K}$ ) in a 1:1 ratio, according to the following chemical reactions:

$$
\begin{gathered}
\mathrm{Ca}\left(\mathrm{H}_{2} \mathrm{PO}_{4}\right)_{2} \rightarrow \mathrm{Ca}\left(\mathrm{PO}_{3}\right)_{2}+2 \mathrm{H}_{2} \mathrm{O} \\
\mathrm{KH}_{2} \mathrm{PO}_{4} \longrightarrow \mathrm{KPO}_{3}+\mathrm{H}_{2} \mathrm{O} \\
\mathrm{Ca}\left(\mathrm{PO}_{3}\right)_{2}+\mathrm{KPO}_{3} \longrightarrow \mathrm{CaKP}_{3} \mathrm{O}_{9}
\end{gathered}
$$


Crystals of $\mathrm{CaKP}_{3} \mathrm{O}_{9}$ were grown by heating a mixture consisting of $9 \mathrm{wt} \% \mathrm{KPO}_{3}$ and $91 \mathrm{wt} \% \mathrm{CaKP}_{3} \mathrm{O}_{9}$ at $1173 \mathrm{~K}$ for about $12 \mathrm{~h}$, followed by cooling at a rate of $6 \mathrm{Kh}^{-1}$ to $997 \mathrm{~K}$, and finally quenching to room temperature.

\subsubsection{9. $\quad \mathrm{CaNa}_{4}\left(\mathrm{P}_{3} \mathrm{O}_{9}\right)_{2}$.}

The title compound was prepared by Abrahams et al. $[58,59]$ as a polycrystalline powder by crystallizing a glass of the stoichiometric composition. A mixture of sodium carbonate $\mathrm{Na}_{2} \mathrm{CO}_{3}$, calcium oxide $\mathrm{CaO}$ and ammonium dihydrogen phosphate $\mathrm{NH}_{4} \mathrm{H}_{2} \mathrm{PO}_{4}$ were ground and heated hour at $1000{ }^{\circ} \mathrm{C}$ for 1 hour until molten, according to the following chemical reactions:

$$
2 \mathrm{Na}_{2} \mathrm{CO}_{3}+\mathrm{CaO}+6 \mathrm{NH}_{4} \mathrm{H}_{2} \mathrm{PO}_{4} \longrightarrow \mathrm{CaNa}_{4}\left(\mathrm{P}_{3} \mathrm{O}_{9}\right)_{2}+2 \mathrm{CO}_{2}+6 \mathrm{NH}_{3}+9 \mathrm{H}_{2} \mathrm{O}
$$

The melt was poured into hot graphite at $350{ }^{\circ} \mathrm{C}$ and allowed to cool slowly to room temperature in a furnace and was then reheated to $600{ }^{\circ} \mathrm{C}$ to facilitate crystallization. Single crystals of $\mathrm{CaNa}_{4}\left(\mathrm{P}_{3} \mathrm{O}_{9}\right)_{2}$ were obtained by slow cooling of the melt in the furnace for 12 hours.

\subsection{0. $\mathrm{CaTI}_{4}\left(\mathrm{P}_{3} \mathrm{O}_{9}\right)_{2}$ and $\mathrm{CaTIP}_{3} \mathrm{O}_{9}$.}

By the conventional solid-state method, Rolaisoa et al. [60] have prepared the two compounds using appropriate stoichiometric amounts of a large excess of phosphoric acid $\mathrm{H}_{3} \mathrm{PO}_{4}$ and calcium $\mathrm{CaCO}_{3}$, and thallium $\mathrm{Tl}_{2} \mathrm{CO}_{3}$ carbonates were mixed at around $400^{\circ} \mathrm{C}$ in an agate mortar, according to the following chemical reactions:

$$
\begin{gathered}
\mathrm{CaCO}_{3}+2 \mathrm{Tl}_{2} \mathrm{CO}_{3}+6 \mathrm{H}_{3} \mathrm{PO}_{4} \longrightarrow \mathrm{CaTl}_{4}\left(\mathrm{P}_{3} \mathrm{O}_{9}\right)_{2}+3 \mathrm{CO}_{2}+9 \mathrm{H}_{2} \mathrm{O} \\
2 \mathrm{CaCO}_{3}+\mathrm{Tl}_{2} \mathrm{CO}_{3}+6 \mathrm{H}_{3} \mathrm{PO}_{4} \longrightarrow 2 \mathrm{CaTlP}_{3} \mathrm{O}_{9}+3 \mathrm{CO}_{2}+9 \mathrm{H}_{2} \mathrm{O}
\end{gathered}
$$

\subsubsection{Crystallographic data.}

The main crystallographic data obtained for the various cyclotriphosphates associated with calcium are classified from the hexagonal to the triclinic system, as illustrated in

\begin{tabular}{|c|c|c|c|c|c|c|c|}
\hline Compound & System & $\begin{array}{l}\text { Space } \\
\text { group }\end{array}$ & $\mathbf{Z}$ & $\begin{array}{l}\mathbf{a}(\AA) \\
\boldsymbol{\alpha}^{\circ}\end{array}$ & $\begin{array}{l}\mathbf{b}(\mathbf{A}) \\
\beta^{\circ}\end{array}$ & $\begin{array}{l}\mathbf{c}(\AA) \\
\gamma^{\circ}\end{array}$ & References \\
\hline $\mathrm{MnCa}_{2}\left(\mathrm{P}_{3} \mathrm{O}_{9}\right)_{2}$ & \multirow{5}{*}{ Hexagonal } & $\mathrm{P}-31 \mathrm{c}$ & 2 & 7.392 & 7.392 & 20.134 & {$[52,53]$} \\
\hline $\mathrm{CaNH}_{4} \mathrm{P}_{3} \mathrm{O}_{9} .3 \mathrm{H}_{2} \mathrm{O}$ & & $\mathrm{P}_{3}$ & 8 & 14.76 & 14.76 & 9.932 & {$[55,56]$} \\
\hline $\mathrm{CaKP}_{3} \mathrm{O}_{9}$ & & $\mathrm{P}-6 \mathrm{c} 2$ & 2 & 6.8090 & 6.8090 & 10.3760 & [47] \\
\hline $\mathrm{CaTI}_{4}\left(\mathrm{P}_{3} \mathrm{O}_{9}\right)_{2}$ & & $\mathrm{P} 3_{1} \mathrm{c}$ & 2 & 7.389 & 7.389 & 19.99 & {$[60]$} \\
\hline $\mathrm{CaNH}_{4} \mathrm{P}_{3} \mathrm{O}_{9}$ & & $\mathrm{P}-62 \mathrm{c}$ & 2 & 6.887 & 6.887 & 10.448 & {$[55,56]$} \\
\hline $\mathrm{CaCsP}_{3} \mathrm{O}_{9}$ & Orthorhombic & Pnma & 4 & 9.8287 & 7.5642 & 12.7905 & [54] \\
\hline $\mathrm{Ca}_{3}\left(\mathrm{P}_{3} \mathrm{O}_{9}\right)_{2} \cdot 10 \mathrm{H}_{2} \mathrm{O}$ & \multirow{5}{*}{ Monoclinic } & $\mathrm{P} 2{ }_{1} / \mathrm{n}$ & 2 & 9.332 & $\begin{array}{l}18.13 \\
106.69 \\
\end{array}$ & 7.841 & [51] \\
\hline $\mathrm{MnCa}_{2}\left(\mathrm{P}_{3} \mathrm{O}_{9}\right)_{2} \cdot 10 \mathrm{H}_{2} \mathrm{O}$ & & $\mathrm{P} 2{ }_{1} / \mathrm{n}$ & 2 & 9.631 & $\begin{array}{l}18.173 \\
109.44 \\
\end{array}$ & 7.976 & {$[52,53]$} \\
\hline $\mathrm{CaRbP}_{3} \mathrm{O}_{9}$ & & $\mathrm{P} 2{ }_{1} / \mathrm{n}$ & 4 & 7.545 & 12.51 & 9.745 & [32] \\
\hline $\mathrm{CaNa}_{4}\left(\mathrm{P}_{3} \mathrm{O}_{9}\right)_{2}$ & & $\mathrm{C} 2 / \mathrm{c}$ & 4 & 13.069 & $\begin{array}{l}8.054 \\
94.60\end{array}$ & 14.164 & {$[58,59]$} \\
\hline $\mathrm{CaTIP}_{3} \mathrm{O}_{9}$ & & $\mathrm{P} 21 / \mathrm{n}$ & 4 & 7.471 & 12.52 & 9.913 & [60] \\
\hline
\end{tabular}
Table 7.

Table 7. Main crystallographic data for the cyclotriphosphate associated with calcium, classified from the 
4.2.1.3. Infrared characterization studies made on $\mathrm{P}_{3} \mathrm{O}_{9}{ }^{3-}$ in $\mathrm{Ca}_{3}\left(\mathrm{P}_{3} \mathrm{O}_{9}\right)_{2} \cdot 10 \mathrm{H}_{2} \mathrm{O}$.

Belaaouad et al. [51] have studied the infrared spectrum of $\mathrm{Ca}_{3}\left(\mathrm{P}_{3} \mathrm{O}_{9}\right)_{2} \cdot 10 \mathrm{H}_{2} \mathrm{O}$ at $25^{\circ} \mathrm{C}$. In the range $4000-1600 \mathrm{~cm}^{-1}$, the IR spectrum showed four stretching bands at 3660,3580 , 1660 , and $1620 \mathrm{~cm}^{-1}$. The bands at 3660 and $3580 \mathrm{~cm}^{-1}$ are attributed to the stretching vibrations of water molecules ( $\mathrm{v} \mathrm{O}-\mathrm{H}$ ) [61-63]. The bands at 1660 and $1620 \mathrm{~cm}^{-1}$ represent the bending vibration of water molecules $(\delta \mathrm{HOH})$ [61-63]. Between 1318 and $668 \mathrm{~cm}^{-1}$, were observed the stretching modes $v_{\text {as }}$ OPO and $v_{s} \mathrm{OP}$ characteristic of phosphates with ring anions $\mathrm{P}_{3} \mathrm{O}_{9}{ }^{3-}$ [64-66], as illustrated in Table 8.

The IR stretching vibrations of (POP) ring groups are observed as a very strong band at $1030 \mathrm{~cm}^{-1}$ for the $\mathrm{U}_{\text {as }} \mathrm{POP}$ asymmetric vibrations and a strong band at $780 \mathrm{~cm}^{-1}$ for the $\mathrm{U}_{\mathrm{s}} \mathrm{OP}$ symmetric vibrations. The vibration corresponding to the differences in observed bands is given in Table 8.

Table 8. Frequencies $\left(\mathrm{cm}^{-1}\right)$ of IR absorption bands for $\mathrm{Ca}_{3}\left(\mathrm{P}_{3} \mathrm{O}_{9}\right)_{2} \cdot 10 \mathrm{H}_{2} \mathrm{O}$.

\begin{tabular}{c|c} 
Infrared $\left(\boldsymbol{v} / \mathbf{c m}^{-1}\right)$ & Assignments [51] \\
\hline $3660 ; 3580$ & vO-H \\
\hline $1660 ; 1620$ & $\delta$ HOH \\
\hline $1318 ; 1272$ & Uas OPO \\
\hline $1174 ; 1120$ & Us $_{\text {OPO }}$ \\
\hline 1030 & Uas POP \\
\hline $880 ; 780 ; 668$ & Us POP \\
\hline $562 ; 514$ & $\delta$ OPO $+\rho$ OPO
\end{tabular}

4.2.2. Cyclotetraphosphates $\mathrm{P}_{4} \mathrm{O}_{12}{ }^{4-}$.

\subsubsection{Synthesis.}

The various synthetic methods of the cyclotetraphosphates associated with calcium are described for the following compounds:

$\mathrm{Ca}_{2} \mathrm{P}_{4} \mathrm{O}_{12}$

This compound was prepared by Shneider et al. [67] by thermal dehydration of the tetrahydrate $\mathrm{Ca}_{2} \mathrm{P}_{4} \mathrm{O}_{12} .4 \mathrm{H}_{2} \mathrm{O}$ under atmospheric pressure at $220{ }^{\circ} \mathrm{C}$, according to the following chemical reaction:

$$
\mathrm{Ca}_{2} \mathrm{P}_{4} \mathrm{O}_{12} .4 \mathrm{H}_{2} \mathrm{O} \rightarrow \mathrm{Ca}_{2} \mathrm{P}_{4} \mathrm{O}_{12}+4 \mathrm{H}_{2} \mathrm{O}
$$

\subsubsection{1. $\mathrm{Ca}_{2} \mathrm{P}_{4} \mathrm{O}_{12} \cdot 4 \mathrm{H}_{2} \mathrm{O}$.}

This salt was prepared by Skogareva et al. [68] by adding a solution of $4.495 \mathrm{~g}$ of $\mathrm{Na}_{4} \mathrm{P}_{4} \mathrm{O}_{12 .} 4 \mathrm{H}_{2} \mathrm{O}$ in $50 \mathrm{ml}$ water to a solution of $2.079 \mathrm{~g}$ of $\mathrm{CaCl}_{2}$ in $10 \mathrm{ml}$ of water, adopting the chemical reactions:

$$
\mathrm{Na}_{4} \mathrm{P}_{4} \mathrm{O}_{12} \cdot 4 \mathrm{H}_{2} \mathrm{O}+2 \mathrm{CaCl}_{2} \longrightarrow \mathrm{Ca}_{2} \mathrm{P}_{4} \mathrm{O}_{12} \cdot \mathrm{H}_{2} \mathrm{O}+4 \mathrm{NaCl}+3 \mathrm{H}_{2} \mathrm{O}
$$

The resulting product was left to stand at room temperature for 2 hours for crystallization. 


\subsubsection{2. $\mathrm{CaK}_{2} \mathrm{P}_{4} \mathrm{O}_{12}$.}

This salt was prepared by Cavero-Ghersi et al. [69] by attacking at $0{ }^{\circ} \mathrm{C}$, the stoichiometric mixture of calcium $\mathrm{CaCO}_{3}$ and potassium $\mathrm{K}_{2} \mathrm{CO}_{3}$ carbonates with a titrated solution of tetrametaphosphoric acid $\mathrm{H}_{4} \mathrm{P}_{4} \mathrm{O}_{12}$, according to the following chemical reaction:

$$
\mathrm{CaCO}_{3}+\mathrm{K}_{2} \mathrm{CO}_{3}+\mathrm{H}_{4} \mathrm{P}_{4} \mathrm{O}_{12} \rightarrow \mathrm{CaK}_{2} \mathrm{P}_{4} \mathrm{O}_{12}+2 \mathrm{CO}_{2}+2 \mathrm{H}_{2} \mathrm{O}
$$

The evaporation at an ambient temperature of the liquor thus obtained leaves $\mathrm{CaK}_{2} \mathrm{P}_{4} \mathrm{O}_{12}$ salt to precipitate.

\subsubsection{3. $\mathrm{Ca}_{4} \mathrm{~K}_{4}\left(\mathrm{P}_{4} \mathrm{O}_{12}\right)_{3} .8 \mathrm{H}_{2} \mathrm{O}$.}

This compound was obtained by Averbuch-Pouchot [70] who has added very slowly to an aqueous solution of potassium cyclotetraphosphate one $\mathrm{K}_{4} \mathrm{P}_{4} \mathrm{O}_{12}$ a concentrated aqueous solution of calcium chloride $\mathrm{CaCl}_{2}$, as illustrated by the chemical reaction:

$$
4 \mathrm{CaCl}_{2}+3 \mathrm{~K}_{4} \mathrm{P}_{4} \mathrm{O}_{12}+8 \mathrm{H}_{2} \mathrm{O} \longrightarrow \mathrm{Ca}_{4} \mathrm{~K}_{4}\left(\mathrm{P}_{4} \mathrm{O}_{12}\right)_{3} .8 \mathrm{H}_{2} \mathrm{O}+8 \mathrm{KCl}
$$

After a few weeks, a crystalline crust was observed. The addition of calcium chloride is then stopped, and the system is kept at room temperature for a few more weeks. After filtration, well-developed crystals of $\mathrm{Ca}_{4} \mathrm{~K}_{4}\left(\mathrm{P}_{4} \mathrm{O}_{12}\right)_{3} .8 \mathrm{H}_{2}$ Ohave been obtained.

\subsubsection{4. $\mathrm{CaNa}_{2} \mathrm{P}_{4} \mathrm{O}_{12} .5 .5 \mathrm{H}_{2} \mathrm{O}$.}

The same author [70] has prepared the $\mathrm{CaNa}_{2} \mathrm{P}_{4} \mathrm{O}_{12} .5 .5 \mathrm{H}_{2} \mathrm{O}$ compound by slow evaporation at room temperature of an aqueous solution of sodium cyclo-tetraphosphate $\mathrm{Na}_{4} \mathrm{P}_{4} \mathrm{O}_{12}$ and calcium chloride in stoichiometric ratio, according to the following $5 \mathrm{H}_{2} \mathrm{O}$ chemical reaction:

$$
\mathrm{CaCl}_{2}+\mathrm{Na}_{4} \mathrm{P}_{4} \mathrm{O}_{12}+5.5 \mathrm{H}_{2} \mathrm{O} \rightarrow \mathrm{CaNa}_{2} \mathrm{P}_{4} \mathrm{O}_{12} .5 .5 \mathrm{H}_{2} \mathrm{O}+2 \mathrm{NaCl}
$$

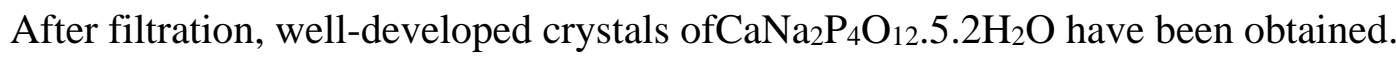

\subsubsection{5. $\mathrm{Ca}(\mathrm{NH} 4)_{2} \mathrm{P}_{4} \mathrm{O}_{12} .2 \mathrm{H}_{2} \mathrm{O}$.}

This crystal has been prepared by Tordjman et al. [71] by slow evaporation technique at $40{ }^{\circ} \mathrm{C}$. To an aqueous solution of sodium cyclotetraphosphate $\mathrm{Na}_{4} \mathrm{P}_{4} \mathrm{O}_{12}$, the authors have very slowly added an aqueous solution of calcium carbonate $\mathrm{CaCO}_{3}$ and ammonium carbonate $\mathrm{NH}_{4} \mathrm{HCO}_{3}$, according to the following chemical reaction:

$$
\mathrm{CaCO}_{3}+2 \mathrm{H}_{4} \mathrm{HCO}_{3}+\mathrm{H}_{4} \mathrm{P}_{4} \mathrm{O}_{12} \longrightarrow \mathrm{Ca}\left(\mathrm{NH}_{4}\right)_{2} \mathrm{P}_{4} \mathrm{O}_{12} \cdot 2 \mathrm{H}_{2} \mathrm{O}+3 \mathrm{CO}_{2}+3 \mathrm{H}_{2} \mathrm{O}
$$

After filtration, $\mathrm{Ca}\left(\mathrm{NH}_{4}\right)_{2} \mathrm{P}_{4} \mathrm{O}_{12} .2 \mathrm{H}_{2} \mathrm{O}$ crystals in the form of long needles were precipitated. The tetrametaphosphoric acid $\mathrm{H}_{4} \mathrm{P}_{4} \mathrm{O}_{12}$ was prepared by the action of water maintained at $0^{\circ} \mathrm{C}$ on $\mathrm{P}_{4} \mathrm{O}_{10}$, according to the following chemical reaction:

$$
\mathrm{P}_{4} \mathrm{O}_{10}+2 \mathrm{H}_{2} \mathrm{O} \longrightarrow \mathrm{H}_{4} \mathrm{P}_{4} \mathrm{O}_{12}
$$




\subsubsection{Crystallographic data.}

Herein, we report the main crystallographic data for the various cyclotetraphosphates associated with calcium classified from the hexagonal to the triclinic system (Table 9).

Table 9. Main crystallographic data for the cyclotetraphosphate associated with calcium, classified from the

\begin{tabular}{|c|c|c|c|c|c|c|c|}
\hline Compound & System & Space group & $\mathbf{Z}$ & $\begin{array}{l}\mathbf{a}(\AA) \\
\alpha^{\circ}\end{array}$ & $\begin{array}{l}\mathbf{b}(\AA) \\
\boldsymbol{\beta}^{\circ}\end{array}$ & $\begin{array}{l}\mathbf{c}(\AA) \\
\gamma^{\circ}\end{array}$ & References \\
\hline $\mathrm{CaK}_{2} \mathrm{P}_{4} \mathrm{O}_{12}$ & Tetragonal & $\mathrm{I}-4$ & 2 & 7.364 & 7.364 & 9.899 & [69] \\
\hline $\mathrm{CaNa}_{2} \mathrm{P}_{4} \mathrm{O}_{12} .5 .5 \mathrm{H}_{2} \mathrm{O}$ & Orthorhombic & Pma2 & 4 & 27.88 & 7.536 & 7.378 & {$[70]$} \\
\hline $\mathrm{Ca}_{2} \mathrm{P}_{4} \mathrm{O}_{12 .} 4 \mathrm{H}_{2} \mathrm{O}$ & \multirow{3}{*}{ Monoclinic } & $\mathrm{P} 21 / \mathrm{n}$ & 4 & 7.668 & $\begin{array}{l}12.895 \\
107.00 \\
\end{array}$ & 7.144 & {$[68]$} \\
\hline $\mathrm{Ca}_{4} \mathrm{~K}_{4}\left(\mathrm{P}_{4} \mathrm{O}_{12}\right)_{3} .8 \mathrm{H}_{2} \mathrm{O}$ & & $\mathrm{P} 21 / \mathrm{a}$ & 2 & 20.38 & $\begin{array}{l}12.683 \\
89.31 \\
\end{array}$ & 7.830 & {$[70]$} \\
\hline $\mathrm{Ca}\left(\mathrm{NH}_{4}\right)_{2} \mathrm{P}_{4} \mathrm{O}_{12} .2 \mathrm{H}_{2} \mathrm{O}$ & & $\mathrm{P} 21 / \mathrm{n}$ & 4 & 16.783 & $\begin{array}{l}10.888 \\
90.92 \\
\end{array}$ & 7.913 & {$[71]$} \\
\hline $\mathrm{Ca}_{2} \mathrm{P}_{4} \mathrm{O}_{12} . \mathrm{H}_{2} \mathrm{O}$ & \multirow{2}{*}{ Triclinic } & $\mathrm{P} 1$ or $\mathrm{P}-1$ & 2 & $\begin{array}{l}7.72 \\
95.9 \\
\end{array}$ & $\begin{array}{l}10.52 \\
105.1 \\
\end{array}$ & $\begin{array}{l}7.15 \\
83.9 \\
\end{array}$ & {$[68]$} \\
\hline $\mathrm{Ca}_{2} \mathrm{P}_{4} \mathrm{O}_{12}$ & & $\mathrm{P} 1$ or $\mathrm{P}-1$ & 2 & $\begin{array}{l}8.02 \\
97.4\end{array}$ & $\begin{array}{l}10.42 \\
109.8\end{array}$ & $\begin{array}{l}7.20 \\
90.4\end{array}$ & {$[67]$} \\
\hline
\end{tabular}

For the anhydrous cyclotetraphosphate compounds, it is clearly stated that the substitution of $2 \mathrm{~K}^{+}$by $\mathrm{Ca}^{2+}$ induces the lowering symmetry from the tetragonal system in $\mathrm{CaK}_{2} \mathrm{P}_{4} \mathrm{O}_{12}$ to the triclinic system in $\mathrm{Ca}_{2} \mathrm{P}_{4} \mathrm{O}_{12}$.

4.2.2.3. Infrared characterization studies made on $\mathrm{P}_{4} \mathrm{O}_{12}{ }^{4-}$ in $\mathrm{Ca}_{2} \mathrm{P}_{4} \mathrm{O}_{12} \cdot 1.5 \mathrm{H}_{2} \mathrm{O}_{2} \cdot 3 \mathrm{H}_{2} \mathrm{O}$.

Skogareva et al. [68] have studied the infrared spectrum of $\mathrm{Ca}_{2} \mathrm{P}_{4} \mathrm{O}_{12} \cdot 1.5 \mathrm{H}_{2} \mathrm{O}_{2} \cdot 3 \mathrm{H}_{2} \mathrm{O}$ at $25^{\circ} \mathrm{C}$, which showed different characteristic regions of the anion $\mathrm{P}_{4} \mathrm{O}_{12}{ }^{4-}$ :

- The spectral region 4000-3000 $\mathrm{cm}^{-1}$, were observed the characteristic $\mathrm{v}(\mathrm{O}-\mathrm{H})$ stretching modes as a wide band around 3560- $3565 \mathrm{~cm}^{-1}$ and a strong band at $3440 \mathrm{~cm}^{-1}$.

- The range 1700-1600 $\mathrm{cm}^{-1}$, where appeared a characteristic water deformation mode $\delta(\mathrm{H}-\mathrm{O}-\mathrm{H})$ of strong intensity at $1628 \mathrm{~cm}^{-1}$.

- Between 1280 and $552 \mathrm{~cm}^{-1}$, appeared the characteristic stretching modes of the $\mathrm{P}_{4} \mathrm{O}_{12}{ }^{4-}$ cycle [72,73]. Four strong bands observed at 1280, 1148,1120, and $1020 \mathrm{~cm}^{-1}$ were assigned to the antisymmetric stretching vibration $\mathrm{Vas}_{\mathrm{a}}(\mathrm{P}-\mathrm{O})$, and the bands at 886,800 , and $740 \mathrm{~cm}^{-1}$ to the symmetric stretching vibration $\mathrm{v}_{\mathrm{s}}(\mathrm{P}-\mathrm{O})$ The symmetric vibration of the $\delta_{\mathrm{s}}$ POP was assigned to the region of $676-440 \mathrm{~cm}^{-1}$ (Table 10 ).

Table 10. Frequencies $\left(\mathrm{cm}^{-1}\right)$ of IR absorption bands for $\mathrm{Ca}_{2} \mathrm{P}_{4} \mathrm{O}_{12} \cdot 1.5 \mathrm{H}_{2} \mathrm{O}_{2} \cdot 3 \mathrm{H}_{2} \mathrm{O}$.

\begin{tabular}{c|c} 
Frequencies $\left(\mathbf{c m}^{-1}\right)$ & Vibrations [68] \\
\hline $3440 ; 3560 ; 3656$ & $v(\mathrm{O}-\mathrm{H})$ \\
\hline 1628 & $\delta(\mathrm{H}-\mathrm{O}-\mathrm{H})$ \\
\hline $1280 ; 1148 ; 1120,1020$ & Uas $(\mathrm{P}-\mathrm{O})$ \\
\hline $886 ; 800 ; 740$ & Us $_{\mathrm{s}}(\mathrm{P}-\mathrm{O})$ \\
\hline $676 ; 612 ; 552$ & Uas $\mathrm{OPO}$ \\
\hline $496 ; 440 ; 400 ; 384 ;$ & $\mathrm{Ca}-\mathrm{O}(\mathrm{H} 2 \mathrm{O})$
\end{tabular}


4.2.3. Cyclohexaphosphates $\mathrm{P}_{6} \mathrm{O}_{18}{ }^{6-}$.

\subsubsection{Synthesis.}

In this part, we present the synthesis of the cyclohexaphosphates associated with calcium by various synthetic methods.

\subsubsection{1. $\mathrm{Ca}_{2} \mathrm{M}_{2} \mathrm{P}_{6} \mathrm{O}_{18} \cdot 8 \mathrm{H}_{2} \mathrm{O}(\mathrm{M}: \mathrm{Li}, \mathrm{Na})$.}

The two isotypic salts were prepared by Averbuch-Pouchot et al. [74] by adding solid gypsum $\mathrm{CaSO}_{4} .2 \mathrm{H}_{2} \mathrm{O}$ to an aqueous solution of lithium and sodium cyclohexaphosphate $\mathrm{Li}_{6} \mathrm{P}_{6} \mathrm{O}_{18} .6 \mathrm{H}_{2} \mathrm{O}, \mathrm{Na}_{6} \mathrm{P}_{6} \mathrm{O}_{18} .6 \mathrm{H}_{2} \mathrm{O}$, according to the following chemical reaction:

$$
\mathrm{M}_{6} \mathrm{P}_{6} \mathrm{O}_{18} \cdot 6 \mathrm{H}_{2} \mathrm{O}+2 \mathrm{CaSO}_{4} .2 \mathrm{H}_{2} \mathrm{O} \longrightarrow \mathrm{Ca}_{2} \mathrm{M}_{2} \mathrm{P}_{6} \mathrm{O}_{18} \cdot 8 \mathrm{H}_{2} \mathrm{O}+2 \mathrm{M}_{2} \mathrm{SO}_{4}(\mathrm{M}: \mathrm{Li}, \mathrm{Na})
$$

After some days of evaporation at room temperature, crystals of $\mathrm{Ca}_{2} \mathrm{Li}_{2} \mathrm{P}_{6} \mathrm{O}_{18} \cdot 8 \mathrm{H}_{2} \mathrm{O}$ and $\mathrm{Ca}_{2} \mathrm{Na}_{2} \mathrm{P}_{6} \mathrm{O}_{18} \cdot 8 \mathrm{H}_{2} \mathrm{O}$ appeared as elongated prisms.

4.2.3.1.2. $\mathrm{Ca}_{2}\left(\mathrm{NH}_{4}\right)_{2} \mathrm{P}_{6} \mathrm{O}_{18} \cdot 6 \mathrm{H}_{2} \mathrm{O}$.

This crystal was prepared by Averbuch-Pouchot et al. [75], by adding solid gypsum $\mathrm{CaSO}_{4} .2 \mathrm{H}_{2} \mathrm{O}$ to an aqueous ammonium cyclohexaphosphate $\left(\mathrm{NH}_{4}\right)_{6} \mathrm{P}_{6} \mathrm{O}_{18} .1 \mathrm{H}_{2} \mathrm{O}$ at room temperature, according to the following chemical reaction:

$$
\left(\mathrm{NH}_{4}\right)_{6} \mathrm{P}_{6} \mathrm{O}_{18} .2 \mathrm{H}_{2} \mathrm{O}+2 \mathrm{CaSO}_{4} \cdot 2 \mathrm{H}_{2} \mathrm{O} \rightarrow \mathrm{Ca}_{2}\left(\mathrm{NH}_{4}\right)_{2} \mathrm{P}_{6} \mathrm{O}_{18} \cdot 6 \mathrm{H}_{2} \mathrm{O}+2\left(\mathrm{NH}_{4}\right)_{2} \mathrm{SO} 4
$$

After some days, the resulting product contains single crystals of $\mathrm{Ca}_{2}\left(\mathrm{NH}_{4}\right)_{2} \mathrm{P}_{6} \mathrm{O}_{18} \cdot 6 \mathrm{H}_{2}$ Osufficiently large and good quality.

\subsubsection{3. $\mathrm{Ca}_{2} \mathrm{Cs}_{2} \mathrm{P}_{6} \mathrm{O}_{18} \cdot 2 \mathrm{H}_{2} \mathrm{O}$.}

This crystal was prepared by Abid et al. [76] by adding dilute cyclohexaphosphoric acid $\mathrm{H}_{6} \mathrm{P}_{6} \mathrm{O}_{18}$ to an aqueous solution of calcium carbonate $\mathrm{CaCO}_{3}$ and cesium carbonate $\mathrm{Cs}_{2} \mathrm{CO}_{3}$ with a stoichiometric ratio $\mathrm{Ca} / \mathrm{Cs}=1$, according to the following chemical reaction:

$$
2 \mathrm{CaCO}_{3}+\mathrm{Cs}_{2} \mathrm{CO}_{3}+\mathrm{H}_{6} \mathrm{P}_{6} \mathrm{O}_{18} \rightarrow \mathrm{Ca}_{2} \mathrm{Cs}_{2} \mathrm{P}_{6} \mathrm{O}_{18} \cdot 2 \mathrm{H}_{2} \mathrm{O}+3 \mathrm{CO}_{2}+\mathrm{H}_{2} \mathrm{O}
$$

The obtained solution is then slowly evaporated at room temperature until large rectangular prisms of $\mathrm{Ca}_{2} \mathrm{Cs}_{2} \mathrm{P}_{6} \mathrm{O}_{18} \cdot 2 \mathrm{H}_{2} \mathrm{O}$ was formed. The cyclohexaphosphoric acid $\mathrm{H}_{6} \mathrm{P}_{6} \mathrm{O}_{18}$ was obtained from an aqueous solution of $\mathrm{Li}_{6} \mathrm{P}_{6} \mathrm{O}_{18} 6 \mathrm{H}_{2} \mathrm{O}$ passed through an ion-exchange resin.

\subsubsection{4. $\mathrm{Ca}_{2} \mathrm{M}_{2} \mathrm{P}_{6} \mathrm{O}_{18} \cdot 6 \mathrm{H}_{2} \mathrm{O}(\mathrm{M}: \mathrm{K}, \mathrm{Tl}, \mathrm{Rb})$.}

These three compounds were prepared by Abid et al. [77] by slowly adding dilute cyclohexaphosphoric acid $\mathrm{H}_{6} \mathrm{P}_{6} \mathrm{O}_{18}$ to an aqueous solution of calcium carbonate $\mathrm{CaCO}_{3}$ and $\mathrm{M}_{2} \mathrm{CO}_{3}[\mathrm{M}=\mathrm{K}, \mathrm{Tl}, \mathrm{Rb}]$ with a stoichiometric ratio $\mathrm{Ca} / \mathrm{M}=1$ according to the flowing reaction:

$$
2 \mathrm{CaCO}_{3}+\mathrm{M}_{2} \mathrm{CO}_{3}+\mathrm{H}_{6} \mathrm{P}_{6} \mathrm{O}_{18}+3 \mathrm{H}_{2} \mathrm{O} \longrightarrow \mathrm{Ca}_{2} \mathrm{M}_{2}{ }_{2} \mathrm{P}_{6} \mathrm{O}_{18} .6 \mathrm{H}_{2} \mathrm{O}+3 \mathrm{CO}_{2}(\mathrm{M}: \mathrm{K}, \mathrm{Tl}, \mathrm{Rb})
$$

After some days of slow evaporation at room temperature, crystals appeared with good quality. 


\subsubsection{Crystallographic data.}

In this part, we reported the main crystallographic data for the various cyclohexaphosphate a ssociated with calcium, classified from the hexagonal to the triclinic system (Table 11).

Table 11. Main crystallographic data for the cyclohexaphosphates associated with calcium, classified from the

\begin{tabular}{|c|c|c|c|c|c|c|c|}
\hline \multicolumn{8}{|c|}{ hexagonal to the triclinic. } \\
\hline Compound & System & $\begin{array}{l}\text { Space } \\
\text { group }\end{array}$ & $\mathbf{Z}$ & $\begin{array}{c}\mathbf{a}(\stackrel{\AA}{\mathbf{A}}) \\
\boldsymbol{\alpha}^{\circ}\end{array}$ & $\begin{array}{c}\mathbf{b}(\AA) \\
\left.\boldsymbol{\beta}^{\circ}\right)\end{array}$ & $\begin{array}{c}\mathbf{c}(\mathbf{A}) \\
\gamma^{\circ}\end{array}$ & References \\
\hline $\mathrm{Ca}_{2}\left(\mathrm{NH}_{4}\right)_{2} \mathrm{P}_{6} \mathrm{O}_{18} \cdot 6 \mathrm{H}_{2} \mathrm{O}$ & Orthorhombic & $\mathrm{P} 22_{1} 2_{1}$ & 2 & 12.821 & 12.537 & 7.029 & [75] \\
\hline $\mathrm{Ca}_{2} \mathrm{Cs}_{2} \mathrm{P}_{6} \mathrm{O}_{18} \cdot 2 \mathrm{H}_{2} \mathrm{O}$ & \multirow[t]{4}{*}{ Monoclinic } & $\mathrm{P} 2_{1} / \mathrm{c}$ & 2 & 9.087 & $\begin{array}{l}12.246 \\
116.98\end{array}$ & 9.895 & [76] \\
\hline $\mathrm{Ca}_{2} \mathrm{~K}_{2} \mathrm{P}_{6} \mathrm{O}_{18} \cdot 6 \mathrm{H} 2 \mathrm{O}$ & & $\mathrm{P} 2_{1} / \mathrm{n}$ & 2 & 7.309 & $\begin{array}{l}11.862 \\
103.22\end{array}$ & 12.335 & [77] \\
\hline $\mathrm{Ca}_{2} \mathrm{Tl}_{2} \mathrm{P}_{6} \mathrm{O}_{18} \cdot 6 \mathrm{H}_{2} \mathrm{O}$ & & $\mathrm{P} 2_{1} / \mathrm{n}$ & 2 & 7.233 & $\begin{array}{c}11.582 \\
99.94 \\
\end{array}$ & 12.193 & [77] \\
\hline $\mathrm{Ca}_{2} \mathrm{Rb}_{2} \mathrm{P}_{6} \mathrm{O}_{18} \cdot 6 \mathrm{H}_{2} \mathrm{O}$ & & $\mathrm{P} 2_{1} / \mathrm{n}$ & 2 & 7.290 & $\begin{array}{l}11.593 \\
100.86\end{array}$ & 2.236 & [77] \\
\hline $\mathrm{Ca}_{2} \mathrm{Li}_{2} \mathrm{P}_{6} \mathrm{O}_{18} \cdot 8 \mathrm{H}_{2} \mathrm{O}$ & \multirow[t]{2}{*}{ Triclinic } & P-1 & 1 & $\begin{array}{c}7.767 \\
105.17 \\
\end{array}$ & $\begin{array}{l}10.144 \\
102.76 \\
\end{array}$ & $\begin{array}{r}7.225 \\
84.95 \\
\end{array}$ & [74] \\
\hline $\mathrm{Ca}_{2} \mathrm{Na}_{2} \mathrm{P}_{6} \mathrm{O}_{18} \cdot 8 \mathrm{H}_{2} \mathrm{O}$ & & P-1 & 1 & $\begin{array}{c}8.031 \\
105.69\end{array}$ & $\begin{array}{l}10.296 \\
103.27\end{array}$ & $\begin{array}{l}7.279 \\
85.30\end{array}$ & [74] \\
\hline
\end{tabular}

The calcium cyclohexaphosphates are all found to be hydrate compounds. It is to note that cyclohexaphosphate with ammonium cations $\left(\mathrm{NH}_{4}\right)_{6} \mathrm{P}_{6} \mathrm{O}_{18} .1 \mathrm{H}_{2} \mathrm{O}$ crystallized in the orthorhombic system, being highly symmetrical rather than the symmetry of others compounds crystallized in monoclinic and triclinic systems.

\subsubsection{Infrared characterization studies made on $\mathrm{P}_{6} \mathrm{O}_{18}{ }^{4-}$ in $\mathrm{Ca}_{2} \mathrm{~K}_{2} \mathrm{P}_{6} \mathrm{O}_{18} \cdot 6 \mathrm{H}_{2} \mathrm{O}$.}

Abid et al. [76] have studied the infrared spectrum of calcium potassium cyclohexaphosphate hexahydrate, $\mathrm{Ca}_{2} \mathrm{~K}_{2} \mathrm{P}_{6} \mathrm{O}_{18} \cdot 6 \mathrm{H}_{2} \mathrm{O}$ at $25^{\circ} \mathrm{C}$ (Table 12). The spectrum exhibits:

- Two broad bands at about $3600-3200 \mathrm{~cm}^{-1}$ and another one at $1650 \mathrm{~cm}^{-1}$ corresponding to the vibration of water molecules, $v(\mathrm{O}-\mathrm{H})$.

- Various stretching vibration bands for which both positions, between 1300 and $600 \mathrm{~cm}^{-1}$, and number are typical of a phosphoric ring anion [77-83]. In this type of anions, the O-P-O vibrations take place at relatively high frequencies, $1200<v_{a s}<1300 \mathrm{~cm}^{-1}$ and 1050 $<v_{\mathrm{s}}<1200 \mathrm{~cm}^{-1}$, and those corresponding to the P-O-P vibrations appear as a broadband Uas around $960 \mathrm{~cm}^{-1}$ and a doublet $U_{s}$ between 800 and $700 \mathrm{~cm}^{-1}$.

Table 12. Frequencies $\left(\mathrm{cm}^{-1}\right)$ of IR absorption bands for $\mathrm{Ca}_{2} \mathrm{~K}_{2} \mathrm{P}_{6} \mathrm{O}_{18} \cdot 6 \mathrm{H}_{2} \mathrm{O}$.

\begin{tabular}{c|c} 
Frequencies $\left(\mathbf{c m}^{-1}\right)$ & Vibrations [76-83] \\
\hline $3600-3200$ & v (O-H) \\
\hline 1650 & $\delta(\mathrm{H}-\mathrm{O}-\mathrm{H})$ \\
\hline $1200-1300$ & vas $_{\text {as }} \mathrm{O}-\mathrm{O}-\mathrm{O}$ \\
\hline $1200-1050$ & vs $_{\mathrm{s}} \mathrm{O}-\mathrm{P}-\mathrm{O}$ \\
\hline 960 & vas $_{\text {as }} \mathrm{P}-\mathrm{O}-\mathrm{P}$ \\
\hline $700-800$ & v $_{\mathrm{s}} \mathrm{P}-\mathrm{O}-\mathrm{P}$
\end{tabular}

\section{Conclusions}

In this review article, we have presented the various chemical methods used to prepare monophosphates and condensed phosphates associated with calcium. Besides, we have reported and analyzed their crystallographic data. The monophosphates containing $\left(\mathrm{PO}_{4}\right)^{3-}$ 
groups crystallized in the hexagonal, rhombohedral, trigonal, orthorhombic, and monoclinic systems, while the compounds with $\left(\mathrm{HPO}_{4}\right)^{2-}$ and $\left(\mathrm{H}_{2} \mathrm{PO}_{4}\right)^{-}$have low symmetry systems (monoclinic and triclinic). The long polyphosphates chain $\left(\mathrm{PO}_{3}^{-}\right) \mathrm{n}$, containing one $\left(\mathrm{PO}_{4}\right)^{3-}$ grouper formula, crystallized in the high possible symmetry (tetragonal systems), against that of formula with two, three, and four $\left(\mathrm{PO}_{4}\right)^{3-}$ groups, which crystallized in the lower symmetry systems (monoclinic, and triclinic). In the anhydrous cyclotetraphosphates, the substitution of $2 \mathrm{~K}^{+}$by $\mathrm{Ca}^{2+}$ induced lowering symmetry from the tetragonal system in $\mathrm{CaK}_{2} \mathrm{P}_{4} \mathrm{O}_{12}$ to the triclinic system in $\mathrm{Ca}_{2} \mathrm{P}_{4} \mathrm{O}_{12}$. The calcium cyclohexaphosphates all hydrate crystallized in the orthorhombic system, as a highly symmetrical system, where the cations are ammonium $\left(\mathrm{NH}_{4}\right)_{6} \mathrm{P}_{6} \mathrm{O}_{18} .1 \mathrm{H}_{2} \mathrm{O}$. Finally, infrared spectroscopy of some characteristic anions $\mathrm{PO}^{3-}$ in $\gamma-$ $\mathrm{Ca}\left(\mathrm{PO}_{3}\right)_{2}, \mathrm{PO}_{4}{ }^{3-}$ in $\mathrm{CaHPO}_{4}, \mathrm{P}_{2} \mathrm{O}_{7}{ }^{4-}$ in $\mathrm{\beta}_{-} \mathrm{Ca}_{2} \mathrm{P}_{2} \mathrm{O}_{7}, \mathrm{P}_{3} \mathrm{O}_{9}{ }^{3-}$ in $\mathrm{MnCa}_{2}\left(\mathrm{P}_{3} \mathrm{O}_{9}\right)_{2}, \mathrm{P}_{4} \mathrm{O}_{12}{ }^{4-}$ in $\mathrm{Ca}_{2} \mathrm{P}_{4} \mathrm{O}_{12} .1 .5 \mathrm{H}_{2} \mathrm{O}_{2} \cdot 3 \mathrm{H}_{2} \mathrm{O}$, and $\mathrm{P}_{6} \mathrm{O}_{18}{ }^{6-}$ in $\mathrm{Ca}_{2} \mathrm{~K}_{2} \mathrm{P}_{6} \mathrm{O}_{18} \cdot 6 \mathrm{H}_{2} \mathrm{O}$ have been reviewed.

\section{Funding}

This research received no external funding.

\section{Acknowledgments}

The authors thank professor Ali Ouasri for the support needed to carry out this work.

\section{Conflicts of Interest}

The authors declare no conflict of interest.

\section{References}

1. Dorozhkin, S. V. Biphasic, triphasic and multiphasic calcium orthophosphates. Acta Biomater 2012, 8, 963977, https://doi.org/10.1016/j.actbio.2011.09.003.

2. I. A. Neacsu, L. V. Arsenie, R. Trusca, I. L. Ardelean, N. Mihailescu, I. N. Mihailescu, C. Ristoscu, C. Bleotu, A. Ficai, and E. Andronescu, Biomimetic Collagen/Zn(2+)-Substituted Calcium Phosphate Composite Coatings on Titanium Substrates as Prospective Bioactive Layer for Implants: A Comparative Study Spin Coating vs. MAPLE. Nanomaterials 2019, 9, 692, https://doi.org/10.3390/nano9050692.

3. Hench, L. L.; Hench, J.W.; Greeenspan, D. C. Bioglass: a short history and bibliography. J. Aust. Ceram.Soc 2004, 40, 1-42, https://doi.org/10.1007/978-94-011-0541-5_1.

4. LeGeros, R. Z. Calcium Phosphate-Based Osteoinductive Materials. Chem. Rev 2008, 108, 4742-4753, https://doi.org/10.1021/cr800427g.

5. Eliaz, N.; Metoki, N.Calcium Phosphate Bioceramics: A Review of Their History, Structure, Properties, Coating Technologies and Biomedical Applications. Materials 2017, 10, 334, https://doi.org/10.3390/ma10040334.

6. Ginebra, M.P.; Traykova, T.; Planell, J.A.Calcium phosphate cements as bone drug delivery systems: a review. J Control Release 2008, 113, 102-110, https://doi.org/10.1016/j.jconrel.2006.04.007.

7. Zerraf, S.; Belhabra, M.; Tridane, M.; Belaaouad, S. Chemical preparations, crystal data for monophosphates and condensed phosphates associated to barium and IR studies of their anions. International Journal of Advanced Research (IJAR) 2019, 2320-5407, http://dx.doi.org/10.21474/IJAR01/8432.

8. Oubouaza, R.; Marouani, H.; Zerraf, S.; Belhabra, M.; Ouasri, A.;Tridane, M.; Belaaouad,S. Chemical preparations, crystal data for monophosphates and condensed phosphates associated to strontium and IR studies of their anions. International Journal of Emerging Trends in Engineering Research (IJETER) 2020, 8, 6587-6598, http://dx.doi.org/10.30534/ijeter/2020/265892020.

9. Marouani, H.; Oubouaza, R.; Zerraf, S.; Ouasri, A.; Tridane, M.; Belaaouad, S. Chemical preparations, crystal data for monophosphates and condensed Phosphates associated to manganese and IR studies of their anions. International Journal of Emerging Trends in Engineering Research(IJETER) 2020, 8, 4784-4798, https://doi.org/10.30534/ijeter/2020/116882020. 
10. Bac, N.Q.; Duc, T. H. Synthesis and characterization of feed grade monocalcium phosphate, $\mathrm{Ca}\left(\mathrm{H}_{2} \mathrm{PO}_{4}\right)_{2} . \mathrm{H}_{2} \mathrm{O}$ in aqueous medium. Vietnam $J$ Sci Technol 2016, 54, 7-14, https://doi.org/10.15625/25252518/54/4A/11972.

11. Dickens, B.; Prince, E.; Schroeder, L.W.; Brown, W.E. $\mathrm{Ca}\left(\mathrm{H}_{2} \mathrm{PO}_{4}\right)_{2}$, a Crystal Structure Containing Unusual Hydrogen Bonding. Acta Crystallogr 1973, B29, 2057-2070, https://doi.org/10.1107/S0567740873006114.

12. Curry, N. A.; Jones, D. W. Crystal Structure of Brushite, Calcium Hydrogen Orthophosphate Dihydrate: A Neutron-diffraction Investigation. J. Chem. Soc 1971, A23, 3725-3729, https://doi.org/10.1039/J19710003725.

13. Dickens, B.; Bowen, J. S.; Brown,W. E. A Refinement of the Crystal Structure of $\mathrm{CaHPO}_{4}($ Synthetie Monetite). Acta Crystallogr 1972, B28,797-806, https://doi.org/10.1107/S056774087200322X.

14. Mathew, M.; Shroeder, L.W.; Dickens, B.; Brown, W. E. The Crystal Structure of $\alpha-\mathrm{Ca}_{3}\left(\mathrm{PO}_{4}\right)_{2}$. Acta Crystallogr 1977, B33, 1325-1333, https://doi.org/10.1107/S0567740877006037.

15. Yashima, M.; Atsushi, S.; Takashi, K.; Akinori, H. Crystal structure analysis of $\beta$-tricalcium phosphate $\mathrm{Ca}_{3}\left(\mathrm{PO}_{4}\right)_{2}$ by neutron powder diffraction. J Solid State Chem 2003, 175, 272-277, https://doi.org/10.1016/S0022-4596(03)00279-2.

16. Dickens, B.; Brown,W. E.; Kruger, G. J.; Stewart, J. M. Ca $4\left(\mathrm{PO}_{4}\right)_{2} \mathrm{O}$, Tetracalcium Diphosphate Monoxide. Crystal Structure and Relationships to $\mathrm{Ca}_{5}\left(\mathrm{PO}_{4}\right)_{3} \mathrm{OH}$ and $\mathrm{K}_{3} \mathrm{Na}\left(\mathrm{SO}_{4}\right)_{2}$. Acta Crystallogr 1973, B29, 20462056, https://doi.org/10.1107/S0567740873006102.

17. Abrouki,Y.; Anouzla, A.; Loukili, H.; Lotfi, R.; Rayadh, A.; Bahlaoui1, A.; Sebti, S.; Zakarya, D.; Zahouily, M. Central Composite Experimental Design Applied to the Catalytic Carbon-Sulfur Bond Formation by Fluorapatite Catalyst. Am. J. Appl. Chem 2013, 1, 22-27, https://doi.org/10.11648/j.ajac.20130102.12.

18. Alamo, J.; Rodrigo, J.L. High temperature neutron diffraction study of $\mathrm{CaZr}_{4}\left(\mathrm{PO}_{4}\right)_{6}$. Solid State Ion 1993, 63, 678-683, https://doi.org/10.1016/0167-2738(93)90178-6.

19. Zatovsky, I.V.; Nataliya, Y.S.; Vyacheslav, N.B.; Nikolay, S.S.; Ivan, V.O.; Oleg, V. S. Synthesis and characterization of phosphates in molten systems $\mathrm{Cs}_{2} \mathrm{O}-\mathrm{P}_{2} \mathrm{O}_{5}-\mathrm{CaO}-\mathrm{M}_{2}^{\mathrm{III}} \mathrm{O}_{3} \quad\left(\mathrm{M}^{\mathrm{III}}=\mathrm{Al}, \mathrm{Fe}, \mathrm{Cr}\right)$. J Solid State Chem 2011,184, 705-711, https://doi.org/10.1016/j.jssc.2011.01.042.

20. Zatovsky, I. V.; Strutynska, N. Y.; Baumer, V. N.; Shishkin, O. V.; Slobodyanik, N.S. The whitlockite-related phosphate $\quad \mathrm{Ca}_{9} \mathrm{Cr}\left(\mathrm{PO}_{4}\right)_{7} . \quad$ Acta Crystallogr https://doi.org/10.1107/S1600536807044765.

21. Ben Chaabane, T.; Smiri-Dogguy, L.; Laligant,Y.; Bail, A. L. Structure of $\mathrm{Na}_{2} \mathrm{Ca}\left(\mathrm{HPO}_{4}\right)_{2}$ determined ab initio from conventional powder diffraction data. European journal of solid state and inorganic chemistry 1997, 34, 937-946, http://pascal-francis.inist.fr/vibad/index.php?action=getRecordDetail\&idt=2356149.

22. Ben Amara, M.; Vlasse, M.; Le Flem, G.; Hagenmuller, P. Structure of the Low-Temperature Variety of Calcium Sodium Orthophosphate, $\mathrm{NaCaPO}_{4}$. Acta Crystallogr 1983, C39, 1483-1485, https://doi.org/10.1107/S0108270183008963.

23. Tortet, L.; Gavarri, J. R.; Nihoul,G.; Dianoux, A. J. Study of protonic mobility in $\mathrm{CaHPO}_{4} \cdot 2 \mathrm{H}_{2} \mathrm{O}$ (brushite) and $\mathrm{CaHPO}_{4}$ (monetite) by infrared spectroscopy and neutron scattering. J. Solid State Chem 1997, 132, 6-16. https://doi.org/10.1006/jssc.1997.7383.

24. El Makhloufy. S.; Majdi. E. M.; Ouasri. A.; Chtita. S.; Saadi. M.; El Ammari. L.; Cherqaouiand. A.; Belaaouad, S. Synthesis, crystal structure, IR, Raman-spectroscopy and DFT computation of monostrontium phosphate monohydrate, $\quad \mathrm{Sr}\left(\mathrm{H}_{2} \mathrm{PO}_{4}\right)_{2} \cdot \mathrm{H}_{2} \mathrm{O}$. J. Coord. Chem 2020, 73, 2328-2346, https://doi.org/10.1080/00958972.2020.1815014.

25. Zerraf, S.; Tridane, M.; Belaaouad, S. Crystal structure, vibrational and spectroscopic study of single crystal $\left(\mathrm{C}_{6} \mathrm{H}_{15} \mathrm{~N}_{4} \mathrm{O}_{2}\right) \mathrm{H}_{2} \mathrm{PO}_{4}$. $\quad \mathrm{H}_{2} \mathrm{O}$. Moroccan Journal of Chemistry 2020, $8, \quad 8-2$, https://doi.org/10.48317/IMIST.PRSM/morjchem-v8i2.16988.

26. Majdi, El.; Zerraf, S. ; Marouani, H.; El Makhloufy, S.; Belhabra, M.; Ouasri, A.; Naimi, Y.; Belaaouad, S. Structural and vibrational study of titanium Monophosphates $\mathrm{Na}_{0.5} \mathrm{M}_{0.25} \mathrm{Ti}_{2}\left(\mathrm{PO}_{4}\right)_{3} \quad(\mathrm{M}=\mathrm{Mn}, \mathrm{Ni})$. Mediterranean Journal of Chemistry 2019, 9, 355-362, https://doi.org/10.13171/mjc01911281083emm.

27. Rothammel, W.; Burzlaff, H.; Specht, R. Structure of calcium metaphosphate $\mathrm{Ca}\left(\mathrm{PO}_{3}\right)_{2}$. Acta Crystallogr 1989, C45, 551-553, https://doi.org/10.1107/S0108270188012922.

28. Averbuch-Pouchot, M-T. Données cristallographiques sur quatre polyphosphates mixtes du type $\mathrm{BaM}^{\mathrm{II}}\left(\mathrm{PO}_{3}\right)_{4}$ pour $\quad \mathrm{M}^{\mathrm{II}}=\mathrm{Mn}, \quad \mathrm{Cd}, \quad \mathrm{Ca} \quad$ et $\mathrm{Hg} . \quad J \quad$ Appl Crystallogr 1975, 8, 389-390, https://doi.org/10.1107/S002188987501076X. 
29. Shieh, M.; Martin, K. J.; Squattrito, P.J.; Clearfiel, A. New low-dimensional zinc compounds containing zincoxygen-phosphorus frameworks: two layered inorganic phosphites and a polymeric organic phosphinate. Inorg.Chem 1990, 29, 958-963, https://doi.org/10.1021/ic00330a012.

30. Abrahams, I.; Hawkes, G. E.; Ahmed, A.; Di Cristina, T.; Demetriou, D. Z.; Ivanova, G.I. Structures of the chain metaphosphates $\mathrm{NaM}\left(\mathrm{PO}_{3}\right)_{3} \quad(\mathrm{M}=\mathrm{Ca}$ or $\mathrm{Sr})$. Magn Reson Chem 2008, 46, 316-322, https://doi.org/10.1002/mrc.2161.

31. Phillips, M. L .F.; Harrison, W.T.A. Synthesis and crystal structure of calcium hydrogenphosphite, $\mathrm{CaHPO}_{3}$. Acta Crystallogr 2019, E75, 997-1000, https://doi.org/10.1107/S2056989019008235.

32. Henry,Y.; Durif, A. Données cristallographiques sur $\mathrm{CaRb}\left(\mathrm{PO}_{3}\right)_{3}$ et $\mathrm{CaRb} 2\left(\mathrm{PO}_{3}\right)_{4}$. Diagramme d'équilibre Ca $\left(\mathrm{PO}_{3}\right)_{2}-\mathrm{Rb} \mathrm{PO}_{3}$. Bulletin de la Société française de Minéralogie et de Cristallographie 1969, 92, 484-486, https://doi.org/10.3406/bulmi.1969.6400.

33. Jackson, L. E.; Kariuki, B. M.; Smith, M. E.; Barralet, J. E.; Wright, A. J. Synthesis and structure of a calcium polyphosphate with a unique criss-cross arrangement of helical phosphate chains. Chem. Mater 2005, 17, 46424646, https://doi.org/10.1021/cm050984x.

34. Han, S.; Li, H.; Yang, Z.; Yu, H. H.; Pan, S. Three new phosphates, $\mathrm{Cs}_{8} \mathrm{~Pb}_{4}\left(\mathrm{P}_{2} \mathrm{O}_{7}\right)_{4}, \mathrm{CsLi}_{7}\left(\mathrm{P}_{2} \mathrm{O}_{7}\right)_{2}$ and $\mathrm{LiCa}$ $\left(\mathrm{PO}_{3}\right)_{3}$ : structural comparison, characterization and theoretical calculation. Dalton Trans 2019, 48, 89488954, https://doi.org/10.1039/C9DT01739A.

35. Riou, D.; Goreaud, M. $\mathrm{CaCuP}_{2} \mathrm{O}_{7}$ : a Structure Closely Related to $\alpha \mathrm{Ca}_{2} \mathrm{P}_{2} \mathrm{O}_{7}$. Acta Crystallogr 1990, C46, 11911193, https://doi.org/10.1107/S0108270189011704.

36. Brown, E. H.; Lehr, J. R.; Smith, J. P.; Frazier, A. W. Fertilizer Materials, Preparation and Characterization of Some Calcium Pyrophosphates. J. Agric. Food Chem 1963, 11, 214-222, https://doi.org/10.1021/jf60127a020.

37. Mathew,M.; Schroeder, L.W. The Crystal Structure of Calcium Ammonium Hydrogenpyrophosphate $\mathrm{CaNH}_{4} \mathrm{HP}_{2} \mathrm{O}_{7}$. Acta Crystallogr 1977, B33, 3025-3028, https://doi.org/10.1107/S056774087701019X.

38. Sandström, M.; Fischer, A.; Boström, D. $\mathrm{CaK}_{2} \mathrm{P}_{2} \mathrm{O}_{7}$. Acta Crystallogr 2003, E59, i139-i141, https://doi.org/10.1107/S1600536803021287.

39. Averbuch-Pouchot, M. T.; Guitel, J. C. Données Cristallochimiques sur Deux Nouveaux Diphosphates Mixtes, $\mathrm{CaNH}_{4} \mathrm{NaP}_{2} \mathrm{O}_{7} .3 \mathrm{H}_{2} \mathrm{O}$ et $\mathrm{CdNH}_{4} \mathrm{NaP}_{2} \mathrm{O}_{7} \cdot 3 \mathrm{H}_{2} \mathrm{O}$ et Structure Cristalline de $\mathrm{CdNH}_{4} \mathrm{NaP}_{2} \mathrm{O}_{7} \cdot 3 \mathrm{H}_{2} \mathrm{O}$. Acta Crystallogr 1977, B33, 3460-3462, https://doi.org/10.1107/S0567740877011194.

40. Cheng, P. T.; Pritzker, K. P. H.; Nyburg, S. C. $\alpha$-Calcium Disodium Pyrophosphate Tetrahydrate. Acta Crystallogr 1980, B36, 921-924, https://doi.org/10.1107/S0567740880004864.

41. Webb, N. C. The Crystal Structure of $\beta-\mathrm{Ca}_{2} \mathrm{P}_{2} \mathrm{O}_{7}$.Acta Crystallogr 1966, 21, 942-948, https://doi.org/10.1107/S0365110X66004225.

42. Boudin, S.; Grandin, A.; Borel, M.; Leclaire ,A.; Raveau, B. Redetermination of the $\beta-\mathrm{Ca}_{2} \mathrm{P}_{2} \mathrm{O}_{7}$ structure. Acta Crystallogr 1993, C49, 2062-2064, https://doi.org/10.1107/S0108270193005608.

43. Zatovsky, I.V.; Strutynska, N.Y.; Hizhnyi, Y.A.; Baumer, V. N.; Ogorodnyk, I.V.; Slobodyanik, N.S.; Odynets, I.V.; Klyui,N.I. New complex phosphates $\mathrm{Cs}_{3} \mathrm{M}^{\mathrm{II}} \mathrm{Bi}\left(\mathrm{P}_{2} \mathrm{O}_{7}\right)_{2}\left(\mathrm{M}^{\mathrm{II}}=\mathrm{Ca}, \mathrm{Sr}, \mathrm{Pb}\right)$ : synthesis, characterization, crystal and electronic structure. Dalton Trans 2018, 47, 2274-2284, https://doi.org/10.1039/C7DT04505K.

44. Lyutsko, V. A.; Lyakhov, A. S.; Frenkel, P. L. A propos des diphosphates doubles de calcium $\mathrm{CaM}_{2} \mathrm{P}_{2} \mathrm{O}_{7}$. Žurnal neorganičeskoj himii 1989, 34, 2190-2193, http://pascalfrancis.inist.fr/vibad/index.php?action=getRecordDetail\&idt=6674125.

45. de Waal, D.; Hutter, C. Vibrational spectra of a solid solution of cadmium and calcium pyrophosphate. Mater.Res. Bull 1994, 29, 1129-1135, https://doi.org/10.1016/0025-5408(94)90182-1.

46. Belhabra, M.; Zerraf, S.; Kheireddine, A.; Altomare, A.; Tridane, M.; Ouasri, A.; Radid, M.; Belaaouad, S. Structural and vibrational study of diphenylhydrazine dihydrogenophosphate single crystal $\left(\mathrm{C}_{6} \mathrm{H}_{9} \mathrm{~N}_{2}\right)_{2} \mathrm{H}_{2} \mathrm{P}_{2} \mathrm{O}_{7}$ (DPHDP). Chem. Data Collect 2018, 13-14, 73-83, https://doi.org/10.1016/j.cdc.2018.01.002.

47. Zerraf, S.; Belhabra, M.; Tridane, M.; Belaaouad, S. Chemical Preparation, Thermal Behavior and IR Studies of the New Chromium Diphosphate Hydrate and Crystal Structure of its Corresponding Anhydrous. Biointerface Res. Appl. Chem 2021, 11, 13412-13420, https://doi.org/10.33263/BRIAC115.1341213420.

48. Chen, W.; Jing, Q.; Zhang, Q.; Lee, M. H., Lu, X.; Wei, P.; Chen, Z. A New Cadmium-Based $\mathrm{Pb}_{2} \mathrm{Cd}_{3}$ $\left(\mathrm{PO}_{4}\right)_{2}\left(\mathrm{P}_{2} \mathrm{O}_{7}\right)$ with Two Types of Isolated $\mathrm{P}-\mathrm{O}$ Groups. Eur. J. Inorg. Chem 2019, 2019, 1273-1278, https://doi.org/10.1002/ejic.201900002.

49. Qi, L.; Chen, Z.; Shi, X.; Zhang, X.; Jing, Q.; Li, N.; Lee, M. H. $\mathrm{A}_{3} \mathrm{BBi}\left(\mathrm{P}_{2} \mathrm{O}_{7}\right)_{2}(\mathrm{~A}=\mathrm{Rb}, \mathrm{Cs} ; \mathrm{B}=\mathrm{Pb}, \mathrm{Ba})$ : Isovalent Cation Substitution to Sustain Large Second-Harmonic Generation Responses. Chem. Mater. 2020, 32, 8713-8723, https://doi.org/10.1021/acs.chemmater.0c03383. 
50. Lu, X.; Chen, Z.; Shi, X.; Jing, Q.; Lee, M. H. Two Pyrophosphates with Large Birefringences and SecondHarmonic Responses as Ultraviolet Nonlinear Optical Materials. Angew. Chem. Int. Ed 2020, 59,1764817656, https://doi.org/10.1002/anie.202007494.

51. Belaaouad, S.; Tridane, M.; Chennak, H.; Tamani, R.; Kenz, A.; Moutaabbid, M. Chemical preparation, thermal behavior, kinetic and infrared studies and quantum chemical calculations of $\mathrm{Ca}_{3}\left(\mathrm{P}_{3} \mathrm{O}_{9}\right)_{2} \cdot 10 \mathrm{H}_{2} \mathrm{O}$, Phosphorus Res. Bull 2007, 21, 60-70, https://doi.org/10.3363/prb.21.60.

52. Tridane, M.; Belaaouad, S.; Sbai, K. Chemical preparations and crystal data for eight new condensed phosphates. Solid State Sci 2000, 2, 701-704, http://dx.doi.org/10.1016/S1293-2558(00)01081-5.

53. Marouani,H.; Tridane,M.;Majdi, E.M.; Zerraf,S.; Belhabra,M.;Belaaouad, S. Engineering Techniques applied for studies by Infrared vibration, crystallographic characterization and Thermal Behaviour of two new cyclotriphosphates. International Journal of Emerging Trends in Engineering Research 2020, 8, 239246, https://doi.org/10.30534/ijeter/2020/30812020.

54. Zatovsky, I. V.; Strutynska, N.Y.; Baumer, V. M.; Slobodyanik, N. S.; Shishkin, O. V. Caesium calcium cyclo-triphosphate, $\quad \mathrm{CsCaP}_{3} \mathrm{O}_{9} . \quad$ Acta $\quad$ Crystallogr $\mathbf{2 0 0 6 ,}$ E62, i263-i265, https://doi.org/10.1107/S160053680604832X.

55. Masse, R.; Durif, A.; Guitel, J. C. Structure cristalline du trimétaphosphate $\mathrm{CaNH}_{4} \mathrm{P}_{3} \mathrm{O}_{9}$ Trimétaphosphates: $\mathrm{CaKP}_{3} \mathrm{O}_{9}, \mathrm{CaCsP}_{3} \mathrm{O}_{9}$ et $\mathrm{CaNH}_{4} \mathrm{P}_{3} \mathrm{O}_{9} .3 \mathrm{H}_{2} \mathrm{O}$. ZeitschriftfürKristallographie-Crystalline Materials 1975, 141 , 113-125, https://doi.org/10.1524/zkri.1975.141.1-2.113.

56. Masse, R.; Grenier, J.C.; Averbuch-Pouchot, M.T.; Tranqui, D.; Durif, A. Étude cristallographique de trimétaphosphates hexagonaux du type $\mathrm{M}^{\mathrm{II}} \mathrm{NH}_{4}\left(\mathrm{PO}_{3}\right)_{3}\left(\mathrm{M}^{\mathrm{II}}=\mathrm{Zn}, \mathrm{Co}, \mathrm{Ca}, \mathrm{Cd}, \mathrm{Mg}, \mathrm{Mn}\right)$. Bulletin de la Société française de Minéralogie et de Cristallographie 1970, 90, 158-161, https://doi.org/10.3406/bulmi.1967.6092.

57. Sandström, M.; Boström, D. Calcium potassium cyclo-triphosphate. Acta Crystallogr 2004, E60, i15-i17, https://doi.org/10.1107/S1600536804000303.

58. Abrahams, I.; Hawkes, G.E.; Ahmed, A.; Franks, K.; Jonathan, C.; Knowles, J.C.; Philippe, R.P.; Nunes, T. Structure of calcium tetrasodiumbis-cyclotriphosphate $\mathrm{CaNa}_{4}\left(\mathrm{P}_{3} \mathrm{O}_{9}\right)_{2}$ by X-ray diffraction and solid-state NMR. Journal of the Chemical Society, Dalton Transactions 2002, 8, 1800-1805, https://doi.org/10.1039/b109036b.

59. Grenier, J. C.; Martin, C.; Durif, A. Nouvelle étude du diagramme d'équilibre $\mathrm{Ca}\left(\mathrm{PO}_{3}\right)_{2}-\mathrm{Na}_{\mathrm{PO}}$. Données cristallographiques sur $\mathrm{CaNa}_{4}\left(\mathrm{PO}_{3}\right)_{6}$ et $\mathrm{CaNa}\left(\mathrm{PO}_{3}\right)_{3}$. Bulletin de la Société française de Minéralogie et de Cristallographie 1970, 93, 52-55, https://doi.org/10.3406/bulmi.1970.6426.

60. Rolaisoa, E. R.; Henry, Y.; Durif, A. Étude des systèmes $\mathrm{Tl} \mathrm{PO}_{3}-\mathrm{Co}\left(\mathrm{PO}_{3}\right)_{2}, \mathrm{TlPO}_{3}-\mathrm{Mg}\left(\mathrm{PO}_{3}\right)_{2}$ et $\mathrm{Tl} \mathrm{PO}_{3}-$ $\mathrm{Ca}\left(\mathrm{PO}_{3}\right)_{2}$. Bulletin de la Société française de Minéralogie et de Cristallographie 1970, 93, 43-51, https://doi.org/10.3406/bulmi.1970.6425.

61. Atibi, A.; El Kababi, K.; Belhabra, M.; Zerraf, S.; Tridane, M.; Belaaouad, S. Chemical preparation, crystal structure and vibrational study of a new dihydrogenotriphosphate trihydrate of 4-aminobenzoic acid fertilizer type NP. J. Coord. Chem 2018, 71, 3510-3520, https://doi.org/10.1080/00958972.2018.1528579.

62. Allouche, F.; Selmi, W.; Zid, M.F.; Benlecheb, T. Theoretical and experimental study of new hybrid compound rich in hydrogen bonding: 2-carboxyanilinium hypophosphite. J. Mol. Struct 2019, 1179, 756763, https://doi.org/10.1016/j.molstruc.2018.11.069.

63. Belhabra, M.; Fahim, I.; Atibi, A.; El Kababi, K.;Ouasri, A.; Zerraf, S.; Belaaouad, S.Vibrational study and thermal behavior of dihydrogenotriphosphate trihydrate of 4-aminobenzoic acid and its anhydrous new form fertilizer type NP.Mediterranean Journal of Chemistry 2019, 8, 270-282, http://dx.doi.org/10.13171/mjc841905308mb.

64. EL Makhloufy, S.; Tridane, M.; Marouani, H.; Zerraf, S.; Belhabra, M.; Cherqaoui, A.; Belaaouad, S. Chemical preparation, thermal behavior and infrared studies of the new cyclotriphosphate tetrahydrate of manganese and distrontium, $\mathrm{MnSr}_{2}\left(\mathrm{P}_{3} \mathrm{O}_{9}\right)_{2} \cdot 4 \mathrm{H}_{2} \mathrm{O}$. Mediterranean Journal of Chemistry 2019, 9, 280-289, https://doi.org/10.13171/mjc941911141082sem.

65. Zerraf, S.; Belhabra, M.; Kheireddine, A.; Lamsatfi, R.; Tridane, M.; Moutaabbid, H.; Belaaouad, S. Reinvestigation of the crystal structure of barium cesium cyclotriphosphate dihydrate and vibrational study. Phosphorus Sulfur Silicon Relat. Elem 2017, 192, 1286-1293, https://doi.org/10.1080/10426507.2017.1333507.

66. Zerraf, S.; Tridane, M.; Belaaouad, S. Data of infrared vibration spectroscopy of cyclotriphosphates. Data in brief 2019, 25, 104075, https://doi.org/10.1016/j.dib.2019.104075. 
67. Schneider, M.; Jost, K. H. Kristallographische Orientierungsbeziehungen zwischen den Phasen der Reaktionsfolge $\mathrm{Ca}_{2}\left[\mathrm{P}_{4} \mathrm{O}_{12}\right] \cdot 4 \mathrm{H}_{2} \mathrm{O} \rightarrow \beta-\left(\mathrm{Ca}_{2}\left[\mathrm{PO}_{3}\right]_{4}\right)_{x}$.Zeitschriftfüranorganische und allgemeine Chemie 1990, 580, 175-180, https://doi.org/10.1002/zaac.19905800121.

68. Skogareva,L. S.; Ivanov, V. K.; Pilipenko, G. P.; Tripol'skaya, T. A. Cyclic Peroxosolvated Calcium Polyphosphates. Russ. J. Inorg.Chem 2012, 57, 6-14, https://doi.org/10.1134/S0036023612010251.

69. Cavero-Ghersi, C.; Durif, A. Données cristallographiques sur cinq nouveaux tétramétaphosphates du type $\mathrm{M}^{\mathrm{II}} \mathrm{M}_{2}^{\mathrm{I}} \mathrm{P}_{4} \mathrm{O}_{12}$. J Appl Crystallogr 1975, 8, 562-564, https://doi.org/10.1107/S0021889875011272.

70. Averbuch-Pouchot, M. T.; Durif, A. Crystal structures of two new types of cyclo-tetraphosphates: tetracalciumtetrapotassiumtris (cyclo-tetraphosphate) octahydrate and calcium disodium cyclo$\begin{array}{lllll}\text { tetraphosphate } \quad \text { 5.5-hydrate. } & \text { Acta } & \text { Crystallogr } & \mathbf{1 9 8 8}, & \text { C44, }\end{array}$ https://doi.org/10.1107/S0108270187010175.

71. Tordjman, I.; Masse, R.; Guitel, J. C. Structure cristalline du tétramétaphosphate de calcium-ammonium dihydraté: $\quad \mathrm{Ca}\left(\mathrm{NH}_{4}\right)_{2} \mathrm{P}_{4} \mathrm{O}_{12} \cdot 2 \mathrm{H}_{2} \mathrm{O}$. Acta Crystallogr 1976, B32, 1643-1645, https://doi.org/10.1107/S0567740876006158.

72. Foumakoye, G.; Cahay, R.;Tarte, P. Étude des spectres vibrationnels des cyclotétraphosphates. Spectrochim Acta 1990, A46, 1245-1257, https://doi.org/10.1016/0584-8539(90)80202-A.

73. Lian, Y. K.; Yu, T.; Xiong, L.; Wu, L. M.; Chen, L. Cyclophosphate MBi $\left(\mathrm{P}_{4} \mathrm{O} 1_{2}\right)(\mathrm{M}=\mathrm{Cs}, \mathrm{Rb})$ : Structure Change Giving Rise to Property Enhancement. Cryst.Growth Des 2020, 20, 6205-6210, https://doi.org/10.1021/acs.cgd.0c00948.

74. Averbuch-Pouchot, M. T.; Durif, A. Crystal Chemistry of cyclo-Hexaphosphates. X. Structure of Diealeium Dilithiumcyclo-Hexaphosphate Octahydrate. Acta Crystallogr 1990, C46, 968-970, https://doi.org/10.1107/S0108270189010383.

75. Averbuch-Pouchot, M. T. Crystal chemistry of cyclo-hexaphosphates. XII. Structure of ammonium calcium cyclo-hexaphosphatehexahydrate. Acta Crystallogr 1990, C46, 2005-2007, https://doi.org/10.1107/S010827019000289X.

76. Abid, S.; Rzaigui, M. Chemical preparation, thermal behavior and crystal structure of calcium-cesium cyclohexaphosphate dehydrate. Mater.Res. Bull 1996, 31, 287-1296, https://doi.org/10.1016/00255408(96)00115-8.

77. Abid, S.; Rzaigui, M. Structural Characterization of a Series of Cyclohexaphosphates: $\mathrm{Ca}_{2} \mathrm{M}_{2} \mathrm{P}_{6} \mathrm{O}_{18} \cdot 6 \mathrm{H}_{2} \mathrm{O}(\mathrm{M}=$ K, Tl, Rb). J. Solid State Chem 1996, 126, 308-313, https://doi.org/10.1006/jssc.1996.0342.

78. Abid, S.; Rzaigui, M.; Bagieu-Beucher, M. Preparation and structure of a series of cyclohexaphosphates: M $\left(\mathrm{p}-\mathrm{CH}_{3} \mathrm{C}_{6} \mathrm{H}_{4} \mathrm{NH}_{3}\right)_{4} \mathrm{P}_{6} \mathrm{O}_{18} \quad 8 \mathrm{H}_{2} \mathrm{O} \quad(\mathrm{M}=\mathrm{Cd}, \mathrm{Co}, \mathrm{Zn}$, and $\mathrm{Cu})$. Mater.Res. Bull 2000, 35, 1933-1944, https://doi.org/10.1016/S0025-5408(00)00394-9.

79. Ameur, I.; Abid, S.; Besbes-Hentati, S.; Al-Deyab, S. S.; Rzaigui, M. Structural, Vibrational, Thermal, and Electrochemical Studies of a Cyclohexaphosphate Complex, $\left(\mathrm{C}_{5} \mathrm{H}_{14} \mathrm{~N}_{2}\right)_{2} \mathrm{Cd}_{2} \mathrm{CL}_{2} \mathrm{P}_{6} \mathrm{O}_{18} . \quad 4 \mathrm{H}_{2} \mathrm{O}$. $\begin{array}{llll}\text { Phosphorus Sulfur Silicon Relat. } & \text { Elem } & \text { 2013, } & \text { 188, }\end{array}$ https://doi.org/10.1080/10426507.2013.777728.

80. Sleymi, S.; Lahbib, K.; Rahmouni, N.; Rzaigui, M.; Besbes-Hentati, S.; Abid, S. Synthesis, characterization, electrochemical investigation and antioxidant activities of a new hybrid cyclohexaphosphate: $\mathrm{Cu}_{1.5} \mathrm{Li}\left(\mathrm{C}_{2} \mathrm{H}_{10} \mathrm{~N}_{2}\right) \mathrm{P}_{6} \mathrm{O}_{18} .7 \mathrm{H}_{2} \mathrm{O} . \quad$ J. $\quad$ Mol. $\quad$ Struct $\quad$ 2017, https://doi.org/10.1016/j.molstruc.2017.05.071.

81. Hamdi, A.; Khedhiri, L.; Kahlaoui, M.; Soudani, S.; Ferretti, V.; Lefebvre, F.; Nasr, C. B. Synthesis, structural characterisations, NMR spectroscopy, Hirshfeld surface analysis and electrochemical study of a new organic cyclohexaphosphate, $\left(\mathrm{C}_{6} \mathrm{H}_{7} \mathrm{FN}\right) \quad{ }_{4}(\mathrm{Li})_{2} \quad\left(\mathrm{P}_{6} \mathrm{O}_{18}\right)\left(\mathrm{H}_{2} \mathrm{O}\right)_{6} . J . \quad$ Mol. $\quad$ Struct $\quad \mathbf{2 0 1 8 ,} \quad 1170, \quad 30-37$, https://doi.org/10.1016/j.molstruc.2018.05.062.

82. Khedhiri, L.;Hamdi, A.; Soudani, S.; Kaminsky, W.;Lefebvre, F.; Jelsch, C.;Nasr, C. B. Crystal structure, Hirshfeld surface analysis, thermal behavior and spectroscopic investigations of a new organic cyclohexaphosphate, $\left(\mathrm{C}_{10} \mathrm{H}_{15} \mathrm{~N}_{2}\right)_{4}(\mathrm{Li})_{2}\left(\mathrm{P}_{6} \mathrm{O}_{18}\right)\left(\mathrm{H}_{2} \mathrm{O}\right)_{6} . \quad$ J. $\quad$ Mol. $\quad$ Struct $\quad \mathbf{2 0 1 8 ,}$ 1171, 429-437, https://doi.org/10.1016/j.molstruc.2018.06.015.

83. Khedhiri, L.; Gannouni, A.; Kahlaoui, M.; Jelsch, C.;Ferretti, V.;Lefebvre, F.; Nasr, C. B. Structural, NMR, IR, Hirshfeld surface, electrochemical and in vitro biochemical investigations of a new organic cyclohexaphosphate, $\left(\mathrm{C}_{6} \mathrm{H}_{6} \mathrm{ClFN}\right)_{4}(\mathrm{Li})_{2}\left(\mathrm{P}_{6} \mathrm{O}_{18}\right)\left(\mathrm{H}_{2} \mathrm{O}\right)_{4} . \quad$ J. $\quad$ Iran. $\quad$ Chem. Soc 2020, 1-15, https://doi.org/10.1007/s13738-020-02078-8). 